\title{
It Is Better to Be Safe When Sorry: Advocating a Federal Rule of Evidence that Excludes Apologies
}

\author{
Jennifer Wimsatt Pusateri*
}

\section{INTRODUCTION}

"Tell your brother you are sorry." There is no great dispute about whether we should teach our children to apologize. As parents, educators, and society we recognize that apologies help heal wounds. They empower the injured parties by acknowledging their hurt and their right not to be victimized in the future. They empower injuring parties to make a repair, to regain their humanness by showing that they understand and regret having been involved in a negative outcome for the injured party. We do not instruct children to engage in a calculated examination of the potential that the injured party contributed to his own harm, or to evaluate whether a child's behavior in fact violated a rule before apologizing; when someone is affronted or harmed, an apology is in order.

Yet in the world of big adult harms we have created a legal system that stifles apologies. Our system allows the admission of apologies in litigation as evidence of fault. Those apologies most likely to be effective at healing wounds are the apologies least likely to be protected and encouraged under the law: apologies that combine self-critical statements with expressions of sympathy. Because our evidentiary system allows only evidence that is actually probative of a legal issue (usually fault) to be admitted, it seems there is a misconception that these full apologies are evidence that could be used to find legal fault. Yet there are many reasons to question this assumption: psychological studies confirm that individuals feel guilt and regret when not at fault; philosophical inquiries affirm the propriety of a self-critical stance for involvement in negative outcomes; and cultural practice confirms that apologies in the absence of blameworthiness are common, well-received, and offered more frequently by some groups than others.

\footnotetext{
* Visiting Professor of Law, The George Washington University Law School. The author is grateful to Marshall Wilson for exceptional research assistance and to Anthony Pusateri for exceptional childcare assistance, without both of whom this article would have been impossible. The author is also grateful to Sarah Buchanan and the editors at the University of Kansas Law Review for making the publication process easy and enjoyable.
} 
Part I of this Article details the benefits of apologies to individuals and society. Specifically, apologies benefit injured parties by restoring their sense of dignity and power, apologizers by affirming their self-worth and morality, and society by decreasing aggression and revenge. Apologies also benefit society by filling a gap in the legal system to address emotional and dignity harms, and, as a result, creating litigation efficiencies in the form of reduced case-filings and increased settlements. Part II outlines the current lack of protection for apologies: apologies are generally admitted in the federal system, and the various states have adopted inconsistent protections that typically protect partial apologies or none at all. Part III argues that despite common assumptions linking fault, guilt, and apology, apologies are made for many reasons besides legal fault. This is intuitive: one can think of circumstances in which people apologize for reasons unrelated to legal fault: social custom, feelings of shame, feelings of sympathy or empathy, or to restore a relationship with an injured party. ${ }^{1}$ Indeed, apologies are made (and should be encouraged) for so many reasons unrelated to legal fault that they are largely not probative of the question of a party's legal liability. Finally, Part IV posits that given their lack of probative value, apologies should be excluded from evidence. And, because the Federal Rules of Evidence govern the admission of evidence in the Federal Courts and act as a model for many state courts, the best way to ensure wide-apology-encouraging protection is to create an exception in the Federal Rules of Evidence that excludes apologies. Part IV also addresses common criticisms to the notion that apologies should be protected.

\section{APOLOGIES TO REDRESS HARM SHOULd BE ENCOURAGED AS A POLICY MATTER.}

Offering an apology when someone is perturbed or when one inadvertently (or intentionally) causes harm or offense does not just illustrate that the actor is polite - though it does do that. Offering and receiving apologies is useful for other reasons as well. They provide benefits to individuals and society, in the form of improved relationships, health, and emotional well-being, a reaffirmation of societal norms, and a decrease in retribution and violence. Apologies address a harm not

1. Christophe Leys, Laurent Licata, Philippe Bernard, \& Cynthie Marchal, The Effects of Offenders' Emotions Versus Behaviors on Victims' Perception of Their Personality: Disentangling the Effects of Felt Guilt and Apologies, 71 SwISS J. PSYCH. 187, 188 (2012). 
addressed by the tort or criminal systems, filling a justice gap in the legal system. And apologies provide litigation efficiencies - key for an oftenoverwhelmed court system.

\section{A. Apologies Humanize Victims and Wrongdoers, Increasing Connection, Civility, and the Likelihood of Healing.}

Apologies "function to regulate and maintain social interactions" including by acknowledging the harmed party's injury, vindicating the victim, and demonstrating that "the transgression is not tied to an internal trait of the offender thus facilitating acceptance and forgiveness." 2 As such, apologies "tend to provide positive psychological, emotional, and legal outcomes for both the apologizer and person receiving the apology." Apologies may "help the injured party to feel less angry and the injurer to feel less guilty" in certain situations. ${ }^{4}$ And, as we teach our children, apologies are polite, helpful, and satisfying for the injured party. ${ }^{5}$ They are the expected response whenever a person is harmed. ${ }^{6}$

1. Apologies provide benefits to injured parties.

Academic studies on apologies tend to focus on two kinds of beneficial effects to the injured party. First, apologies have been shown to have positive effects on physical and mental health. Second, apologies restore self-esteem and dignity to injured parties. Both of these benefits

\footnotetext{
2. Rebecca L. Thomas \& Murray G. Millar, The Impact of Failing to Give an Apology and the Need-for-Cognition on Anger, 27 CURRENT PSYCH. 126, 126 (2008) (citing Bruce W. Darby \& Barry R. Schlenker, Children's Reactions to Apologies, 43 J. PERSONALITY \& SOC. PSYCH. 742, 742 (1982); Ken-ichi Ohbuchi \& Kobun Sato, Children's Reactions to Mitigating Accounts: Apologies, Excuses, and Intentionality of Harm, 134 J. Soc. PsYCH. 5, 5 (1994); Erving Goffman, On Face-Work: An Analysis of Ritual Elements in Social Interaction, 18 PSYCHIATRY: INTERPERSONAL \& BIOLOGICAL Processes 213, 213-14 (1955); Laura N. May \& Warren H. Jones, Does Hurt Linger? Exploring the Nature of Hurt Feelings Over Time, 25 CuRRent Psych.: DeVElopMental, Learning, PERSONALITY, SOC. 245, 245-56 (2007); Seiji Takaku, The Effects of Apology and Perspective Taking on Interpersonal Forgiveness: A Dissonance - Attribution Model of Interpersonal Forgiveness, 141 J. SOC. PSYCH. 494, 506 (2001)).

3. Chandler Farmer, Striking a Balance: A Proposed Amendment to the Federal Rules of Evidence Excluding Partial Apologies, 2 Belmont L. REV. 243, 258 (2015) (citing Jeffrey S. Helmreich, Does 'Sorry' Incriminate? Evidence, Harm and the Protection of Apology, 21 CORNELL J.L. \& PUB. POL'Y 567, 574-75 (2012)).

4. Jonathan R. Cohen, Advising Clients to Apologize, 72 S. CAL. L. REV. 1009, 1016 (1999).

5. Takaku, supra note 2, at 495 .

6. See Thomas \& Millar, supra note 2, at 127 (citing Naomi Sugimoto, Norms of Apology Depicted in U.S. American and Japanese Literature on Manners and Etiquette, 22 INT'L J. INTERCULTURAL REL. 251, 253-55 (1998)).
} 
may relate, in part, to the capacity of apologies to induce forgiveness.

It is both intuitive and confirmed by research that apologies facilitate forgiveness. ${ }^{7}$ Individuals who have been hurt by another commonly experience a stress reaction associated with many negative emotions including "anger, hatred, hostility, resentment, bitterness, fear, and anxiety." Individuals who have been victimized "commonly experience feelings of injustice and want actions to be taken to restore justice." 9 Research suggests that the process of forgiveness serves as an effective coping mechanism through which an injured party is able to replace these negative emotions and stress reactions with more positive ones. ${ }^{10}$ It reflects a "deliberate attempt to let go of negative emotions towards the offender and refrain from causing the offender harm even if considered deserved." 11 Though the process of forgiveness is complex, ${ }^{12}$ this process appears to be facilitated by effective apologies.

Studies have suggested this may be because an apology breaks the perceived link between the transgression and the underlying traits of the transgressor, which facilitates forgiveness. ${ }^{13}$ Another theory is that apologies lead injured parties to take a more benevolent view of transgressors and hold them less responsible for the transgressions (because the injured party is more likely to view the "transgressions as less internal, less controllable, and less stable"). ${ }^{14}$ This, "in turn, increase[s]

7. See Joost M. Leunissen, David de Cremer, Christopher P. Reinders Folmer, \& Marius van Dijke, The Apology Mismatch: Asymmetries Between Victim's Need for Apologies and Perpetrator's Willingness to Apologize, 49 J. EXPERIMENTAL SOC. PSYCH. 315, 322 (2013) (concluding, among other things, that victims tend to forgive transgressors more often when they receive an apology); Takaku, supra note 2, at 496. Relatedly, unforgiveness has been "hypothesized to be directly related to the amount of remaining injustice being experienced (called the injustice gap, by Exline et al. 2003)." Everett L. Worthington, Jr., Charlotte Van Oyen Witvliet, Pietro Pietrini, \& Andrea J. Miller, Forgiveness, Health, and Well-Being: A Review of Evidence for Emotional Versus Decisional Forgiveness, Dispositional Forgivingness, and Reduced Unforgiveness, 30 J. BEHAV. MED. 291, 292 (2007).

8. Kelly S. Flanagan, Kristin K. Vanden Hoek, Jennifer M. Ranter, \& Holly A. Reich, The Potential of Forgiveness as a Response for Coping with Negative Peer Experiences, $35 \mathrm{~J}$. Adolescence 1215, 1216 (2012) (citing Everett L. WorThington, JR., Forgiveness AND RECONCILIATION: THEORY AND APPLICATION (2006)).

9. Michael Wenzel \& Tyler G. Okimoto, How Acts of Forgiveness Restore a Sense of Justice: Addressing Status/Power and Value Concerns Raised by Transgressions, 40 EUR. J. SOC. PSYCH. 401, 401 (2010).

10. Flanagan et al., supra note 8, at 1216, 1221.

11. Wenzel \& Okimoto, supra note 9, at 401 (emphasis in original).

12. Flanagan et al., supra note 8, at 1216.

13. Takaku, supra note 2, at 495 .

14. Id. 
the likelihood of forgiveness." 15 Relatedly, when victims are able to empathize with the "perspective of the transgressor," apologies are more likely to bring about forgiveness. ${ }^{16}$ Whatever the underlying psychological reasons for this phenomenon, the link between apology and forgiveness is well-supported. ${ }^{17}$

The benefits of forgiveness ${ }^{18}$ for injured parties are significant. ${ }^{19}$ Forgiveness can provide positive mental and physical outcomes for injured parties. ${ }^{20}$ There are indications that forgiveness may improve cardiovascular outcomes and reduce chronic pain experiences. ${ }^{21}$ Adolescent victims who report higher levels of forgiveness have higher self-esteem and lower social anxiety. ${ }^{22}$ Further, forgiveness can "help restore a sense of justice in the forgiver" because "there is power in

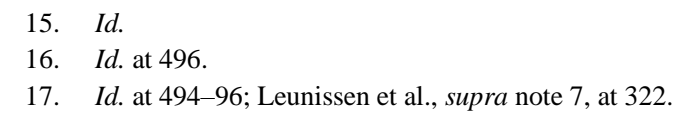

18. Unlike apologies which are necessarily between two (or more) individuals, forgiveness can be viewed as a coping mechanism by an injured party that is independent from the actions of the offender. Flanagan et al., supra note 8, at 1216. It has been defined by academics as "a distinct and complex coping response that addresses cognitive, emotional and behavioral effects of the offense" that "involves transformations within the individual, including a cessation of negative emotions, thoughts, judgments, and motivations, as well as an increase in a prosocial, constructive approach toward the offender." Id. (citations omitted). Indicators of forgiveness include "(a) non-negative or even positive sentiments towards the offender, (b) non-punitive or even constructive responses vis-àvis the offender (e.g. comfort) and (c) non-avoidance or even active repair of the relationship with the offender." Wenzel \& Okimoto, supra note 9, at 402.

19. It is worth distinguishing emotional forgiveness from the expression of forgiving. Although most studies focus on the emotional experience of the victim and the presence of indicators of forgiveness, at least one study has found that expressions of forgiveness, regardless of the emotional experience underlying those expressions, can both provide benefits to the forgiving party and increase emotional forgiveness. Wenzel \& Okimoto, supra note 9, at 402.

20. See id. at 401; Worthington et al., supra note 7, at 298.

21. See Worthington et al., supra note 7, at 298-99.

22. Flanagan et al., supra note 8, at 1221. Flanagan reasoned, in the context of early adolescent victims, that this may be because forgiveness represents a response that provides victimized youth, who often feel powerless, "with a choice in how they want to feel and act in peer situations." Id. (citing Luke A. Egan \& Natasha Todorov, Forgiveness as a Coping Strategy to Allow School Students to Deal with the Effects of Being Bullied: Theoretical and Empirical Discussion, 28 J. Soc. \& CLINICAL PSYCH. 198, 204-05 (2009)). Flanagan further notes:

This sense of agency may decrease feelings of helplessness and increase positive self-perceptions. Engaging in perspective-taking as part of the forgiveness process, might decrease self-blame and dissipate some level of anger, resentment, and shame. For bully-victims, the perspective-taking and empathy involved in forgiveness might decrease attributional biases, anger, and vengefulness.

Id. 
forgiveness[:]" it restores power and a sense of control to victims. ${ }^{23}$

Even without the ancillary benefit of increasing forgiveness, "[a]pologies alone may... catalyze radical changes in individuals or groups, influencing their capacity to repair and eventually mourn that which was damaged or destroyed." ${ }^{24}$ By acknowledging suffering and accepting responsibility for the actor's role in having caused harm, even lawful harm, apologies demonstrate respect for the dignity and humanity of victims. ${ }^{25}$ They can improve the harmed party's sense of self-worth by demonstrating respect. ${ }^{26}$ They empower individuals who have experienced a loss of power and self-worth by being harmed by another. ${ }^{27}$

These effects are particularly strong for apologies in which the harming party accepts responsibility for his actions, whether explicitly or implicitly. Such an apology conveys to the injured party that the harming party understands that he caused harm and promises not to engage in harmcausing conduct in the future. ${ }^{28}$ This acknowledgement of responsibility has the effect of restoring power to the harmed party. ${ }^{29}$ For injured parties, an expression of remorse from a transgressor can restore a sense of equity and alleviate his or her feelings of injustice. ${ }^{30}$

Conversely, failing to apologize, even in the case of lawfully inflicted

23. Wenzel \& Okimoto, supra note 9, at 402, 404 (citation omitted).

24. Isaac Tylim, The Power of Apologies in Transforming Resentment into Forgiveness, 2 INT'L. J. APPLIED PsychOANALYTIC STUD. 260, 269 (2005).

25. See Lesley Wexler \& Jennifer K. Robbennolt, Designing Amends for Lawful Civilian Casualties, 42 YALE J. INT'L L. 121, 150-51 (2017).

26. David De Cremer \& Barbara C. Schouten, When Apologies for Injustice Matter: The Role of Respect, 13 EUR. PSYCHOLOGIST 239, 244 (2008). Apologies can benefit the harmed because "feeling respected signals that one is recognized and accepted, by others, as a person of worth, value, and equal standing." Id. at 240 (citations omitted). Ultimately, "respect and apology combine to make the victim feel good about himself or herself." Id. at 244.

27. Nurit Shnabel \& Arie Nadler, A Needs-Based Model of Reconciliation: Satisfying the Differential Emotional Needs of Victim and Perpetrator as a Key to Promoting Reconciliation, $94 \mathrm{~J}$. PERSONALITY \& SOC. PSYCH. 116, 117, 129-30 (2008). Okimoto and Wenzel explained: "transgressions can upset the status and power balance between offenders, victims, and society as a whole. When victims interpret an injustice as a disruption of this status and power equilibrium, their status/power becomes a principal concern, relative to the offender and within the group in which the injustice occurred." Tyler G. Okimoto \& Michael Wenzel, The Symbolic Meaning of Transgressions: Towards a Unifying Framework of Justice Restoration, in JUSTICE 291, 292 (Karen A. Hegtvedt \& Jody Clay-Warner eds., 2008); see also Carl D. Schneider, What it Means to be Sorry: The Power of Apology in Mediation, 17 MEDIATION Q. 265, 271-73 (2000).

28. Wexler \& Robbennolt, supra note 25, 156-57.

29. See Shnabel \& Nadler, supra note 27, at 117; Okimoto \& Wenzel, supra note 27, at 31013.

30. See Roy F. Baumeister, Arlene M. Stillwell, \& Todd F. Heatherton, Guilt: An Interpersonal Approach, 115 PSYCH. BULL. 243, 259-61 (1994). 
harms, may be felt by victims as causing additional harm. ${ }^{31}$ Individuals who are harmed but do not receive an apology may view the failure to apologize as further provocation and as either a refusal to acknowledge that harm has been done or as communicating that the harm was intentional. ${ }^{32}$ Where the norm of apologizing following harm is violated, the harmed individual is apt to experience increased levels of anger toward the individual who violated the norm. ${ }^{33}$

Unsurprisingly, failure to receive an apology and the failure to forgive are both associated with negative effects for injured parties. The failure to forgive has been linked to depression, anxiety, hostility, and adverse health effects. ${ }^{34}$ There are also indications that chronic unforgiving could contribute to cardiovascular problems like high blood pressure and heart disease and may also lead to changes in the functioning of the sympathetic nervous system, endocrine system, and immune system. ${ }^{35}$ By facilitating forgiveness, apologies help alleviate those adverse effects.

2. Apologies provide benefits to apologizers.

"Apologizing is uncomfortable, creates vulnerability, and is hard to do effectively," $"$ but can create benefits for those who do so.

Apologizing can free an injurer of guilt from having caused harm. ${ }^{37}$ In many religious and ethical systems, apologizing is an important part of moral behavior, such that apologizing can help the apologizer view him or

\footnotetext{
31. Wexler \& Robbennolt, supra note 25, at 149-51.

32. Thomas \& Millar, supra note 2, at 127.

33. Id. (citing Robert B. Cialdini, Raymond R. Reno, \& Carl A. Kallgren, A Focus Theory of Normative Conduct: Recycling the Concept of Norms to Reduce Littering in Public Places, $58 \mathrm{~J}$. PERSONALITY \& SOC. PSYCH. 1015, 1015-16 (1990); Carl A. Kallgren, Raymond R. Reno, \& Robert B. Cialdini, A Focus Theory of Normative Conduct: When Norms Do and Do Not Affect Behavior, 26 Personality \& Soc. PSYCH. Bull. 1002, 1008-11 (2000); Dale T. Miller, Disrespect and the Experience of Injustice, 52 ANN. REV. PSYCH. 527, 532-35 (2001); Ken-ichi Ohbuchi, Toru Tamura, Brian M. Quigley, James T. Tedeschi, Nawaf Madi, Michael H. Bond, \& Amelie Mummendey, Anger, Blame, and Dimensions of Perceived Norm Violations: Culture, Gender, and Relationships, $34 \mathrm{~J}$. APPLIED SOC. PSYCH. 1587, 1588 (2004)).

34. See Charlotte vanOyen Witvliet, Thomas E. Ludwig, \& Kelly L. Vander Laan, Granting Forgiveness or Harboring Grudges: Implications for Emotion, Physiology, and Health, 12 PsYCH. SCI. 117, 121-22 (2001).

35. Id. at 122 .

36. Wexler \& Robbennolt, supra note 25 , at 159.

37. Negative feelings, including regret, self-blame, and frustration, tend to persist for those transgressors who do not apologize. Julie Juola Exline, Lise Deshea, \& Virginia Todd Holeman, Is Apology Worth the Risk? Predictors, Outcomes, and Ways to Avoid Regret, 26 J. Soc. \& CLINICAL PSYCH. 479, 499 (2007).
} 
herself as a better person by virtue of the apology. ${ }^{38}$ Indeed, studies support the notion that when one's actions result in harm to another, that individual's self-image and public moral image is damaged. ${ }^{39}$ Apologizing (particularly where that apology is accepted by the harmed party) can restore the harming party's "sense of belongingness and social acceptance." 40 It appears to be associated with positive impacts on "psychological well-being, positive emotional health and authentic pride." $" 41$

Individuals who apologize for causing harm are generally viewed as more empathetic and less unpleasant, and people tend to feel less aggression towards them. ${ }^{42}$ Indeed, even where the apologizer is "clearly not responsible" for an undesirable circumstance, the party receiving an apology is more likely to trust and attribute positive attributes to the apologizer. $^{43}$

And, as discussed above, apologies can facilitate forgiveness by the injured party. In addition to benefiting the injured party, forgiveness conveys collateral benefits to the transgressor. Transgressors who apologize tend to be viewed more favorable by injured parties and others which facilitates forgiveness, and may itself provide a benefit to transgressors. ${ }^{44}$ Additionally, transgressors may be less likely to repeat offenses when they receive forgiveness (and more likely to offend again

\footnotetext{
38. Wexler \& Robbennolt, supra note 25, at 176-77.

39. Shnabel \& Nadler, supra note 27, at 120, 130.

40. Id. at 129-30. Indeed, giving an apology can restore an offender's perceptions that they are "“social beings' acting in line with their community's normative framework." Leys et al., supra note 1 , at 191.

41. Alyson Byrne, Julian Barling, \& Kathryne E. Dupré, Leader Apologies and Employee and Leader Well-Being, 121 J. Bus. ETHICs 91, 91 (2014).

42. Ken-ichi Ohbuchi, Masuyo Kameda, \& Nariyuki Agarie, Apology as Aggression Control: Its Role in Mediating Appraisal of and Response to Harm, 56 J. PERSONALITY \& SOC. PSYCH. 219, 224-26 (1989).

43. Alison Wood Brooks, Hengchen Dai, \& Maurice E. Schweitzer, I'm Sorry About the Rain! Superfluous Apologies Demonstrate Empathic Concern and Increase Trust, 5 Soc. PsYCH. \& PERSONALITY SCI. 467, 467, 472-73 (2014) (emphasis in original).

44. See Gregg J. Gold \& Bernard Weiner, Remorse, Confession, Group Identity, and Expectancies About Repeating a Transgression, 22 BASIC \& APPLIED SOC. PSYCH. 291, 298-99 (2000) (concluding that whether or not someone has been harmed, people view those who have broken a rule more favorably when they express remorse, which tends to promote forgiveness); Benjamin A. Tabak, Michael E. McCullough, Lindsey R. Luna, Giacomo Bono, \& Jack W. Berry, Conciliatory Gestures Facilitate Forgiveness and Feelings of Friendship by Making Transgressors Appear More Agreeable, 80 J. PERSONALITY 503, 528-29 (2012) (concluding that aggrieved parties tend to view their transgressors as more agreeable when they apologize, which facilitates forgiveness); Wenzel \& Okimoto, supra note 9, at 405 (noting "that victims are more likely to forgive when the offender offers an apology").
} 
when forgiveness is withheld). ${ }^{45}$ But, even when apologies are not accepted, they "le[ad] to (non-significantly) greater sympathy for the offender, reduced retributivism and increased willingness to reconcile." ${ }^{\prime 4}$ Finally, those who apologize may receive a tangible benefit from their apology: injured parties tend to recommend more lenient punishments when they receive an apology. ${ }^{47}$

3. Apologies benefit society by creating a more connected, respectful populous.

Apologies, as a matter of manners, promote civility and respectfulness. ${ }^{48}$ They reaffirm societal values (and the transgressor's acceptance of those values) and respect for others. ${ }^{49}$ Because individuals who "refuse to play by the rules can be a danger to the very integrity and safety of the group," expressions of remorse by rule-breakers can signal that the transgressor has internalized the rules and shares the values of the group, thus restoring harmony within the group. ${ }^{50}$ Relatedly, apologies have the potential to reduce the desire for revenge among victims and can encourage victims to refrain from aggression against transgressors. ${ }^{51}$ Victims who receive an apology may be less likely to retaliate than those who do not. ${ }^{52}$ They are effective at promoting fairness perceptions (as

45. Harry M. Wallace, Julie Juola Exline, \& Roy F. Baumeister, Interpersonal Consequences of Forgiveness: Does Forgiveness Deter or Encourage Repeat Offenses?, 44 J. EXPERIMENTAL SOC. PSYCH. 453, 458-59 (2008).

46. Wenzel \& Okimoto, supra note 9 , at 415.

47. Alayna Jehle, Monica K. Miller, Markus Kemmelmeier, \& Jonathan Maskaly, How Voluntariness of Apologies Affects Actual and Hypothetical Victims' Perceptions of the Offender, 152 J. SOC. PSYCH. 727, 742 (2012). Relatedly, forgiveness, and the associated restoration of justice, "alleviates [the victim's] beliefs that the offender deserves to be punished and increases their willingness to continue a relationship with the offender." Wenzel \& Okimoto, supra note 9, at 414.

48. Within organizations, apologies promote cooperation and help reduce conflict. See Byrne et al., supra note 41, at 103-04; William P. Bottom, Kevin Gibson, Steven E. Daniels, \& J. Keith Murnighan, When Talk Is Not Cheap: Substantive Penance and Expressions of Intent in Rebuilding Cooperation, 13 ORG. SCI. 497, 509-10 (2002).

49. See De Cremer \& Schouten, supra note 26, at 244; Tylim, supra note 24, at 262.

50. Gold \& Weiner, supra note 44, at 299; see also Wenzel \& Okimoto, supra note 9, at 404 (explaining that a transgression may be seen "as a violation of values that were presumed to be shared [by] ... the wider community" which can serve as a threat to these values and "the social identity they define") (citations omitted).

51. See Ohbuchi et al., supra note 42, at 222; Wenzel \& Okimoto, supra note 9, at 414-15.

52. Marti Hope Gonzales, Julie Haugen Pederson, Debra J. Manning, \& David W. Wetter, Pardon My Gaffe: Effects of Sex, Status, and Consequence Severity on Accounts, 58 J. PERSONALITY \& SOC. PSYCH. 610, 611 (1990) (citing Ohbuchi et al., supra note 42). 
well as trust perceptions). ${ }^{53}$ Ultimately, societies in which individuals are willing to share and respect the vulnerabilities implied by apologies exhibit greater respect for individual well-being. ${ }^{54}$

Making amends, even for lawful harms, can "demonstrate to individual victims and their communities a respect for their humanity." They can reduce inter-group hostility, decrease the desire for retribution, and promote reconciliation between social groups. ${ }^{56}$ And they also serve to resolve conflict and increase prosocial interactions (even feelings of friendship) between the harmed party and transgressor. ${ }^{57}$

When apologies work, that is, when they induce forgiveness, they can break "cycle[s] of resentment, aggression, and violence." ${ }^{.5}$ Indeed, forgiveness "is central to the containment of social conflict, [and] the maintenance of social relationships ...."59 It recreates a sense of justice by restoring the belief that the offender shares the same values of the victim and by returning status and power to the victim "thus correct[ing] a status/power imbalance caused by the transgression...." 60 And, through the restoration of justice, forgiveness offers "benefits in terms of de-escalation, reconciliation and peace. ${ }^{\prime 61}$

\section{B. Apologies Redress Harms Distinct from Those Addressed by the Tort System.}

Addressing emotional injuries and harm to dignity is not generally the work of the legal system in the U.S. The tort and criminal systems focus on physical and economic injuries - and, in the case of the criminal system, the societal harms that arise from someone breaking the rules.

53. De Cremer \& Schouten, supra note 26, at 244.

54. See generally Brené Brown, Daring Greatly: How the Courage to Be Vulnerable TRANSFORMS THE WAY WE Live, LOVE, PARENT, AND LEAD (1st ed. 2012) (discussing vulnerability, shame, apology, and their impacts on society).

55. Wexler \& Robbennolt, supra note 25, at 153 (emphasis added).

56. Diana J. Leonard, Diane M. Mackie, \& Eliot R. Smith, Emotional Responses to Intergroup Apology Mediate Intergroup Forgiveness and Retribution, 47 J. EXPERIMENTAL SOC. PSYCH. 1198, 1202-03 (2011).

57. Tabak et al., supra note 44, at 527-29.

58. Tylim, supra note 24, at 262. The feelings of insult, resentment, and humiliation that accompany the moral injury associated with being wronged motivate injured parties to seek revenge and perpetuate harmful cycles of social behavior. Id. But, successful apologies can break these cycles. Id.

59. Wenzel \& Okimoto, supra note 9, at 401.

60. Id. at 414 .

61. Id. at 402 (citations omitted). 
Apologies do not decrease physical harm or economic loss, and though they can reflect an individual's acknowledgment that he has harmed others through his violation of a societal rule, they do not displace the retributive or deterrent functions of the criminal system. ${ }^{62}$ Instead, apologies address a different category of harms - the delta between the redress provided by the law and the full redress needed for the injured person to have his sense of justice restored. The emotional and moral injuries to dignity that result from having been harmed reflect this delta. ${ }^{63}$

1. The tort and criminal systems create a delta between the compensation they provide for injured parties and the redress needed to restore the injured party's sense of justice.

"Tort law gives victims only money damages; it does not elicit apologies, provide care, change risky behavior, or punish." ${ }^{64}$ As such, the tort system largely focuses on compensatory justice: the notion of restoring the situation to an earlier state of affairs and, in effect, "undoing the harm done ... through restitution (returning monetary losses to the victim) or reparations (compensation beyond material loss)," i.e. compensating the victim with money. ${ }^{65}$ And, in doing so, it places a "higher value ... on physical injury and property loss than on emotional and relational harm." ${ }^{66}$ Relatedly, it tends to favor "pecuniary or economic losses, such as lost wages or medical expenses, over nonpecuniary or noneconomic losses, such as pain and suffering, mental distress, lost companionship and society, loss of enjoyment of life, and punitive damages." ${ }^{\prime 67}$ Recovery for pain and suffering or other mental or emotional distress has historically been very limited and only "parasitic" of claims

62. See Stephanos Bibas \& Richard A. Bierschbach, Integrating Remorse and Apology into Criminal Procedure, 114 YALE L. J. 85, 144 (2004).

63. See, e.g., De Cremer \& Schouten, supra note 26, at 244; Shnabel \& Nadler, supra note 27, at 117, 129-30; Okimoto \& Wenzel, supra note 27, at 310-13.

64. Richard Abel, General Damages Are Incoherent, Incalculable, Incommensurable, and Inegalitarian (but Otherwise a Great Idea), 55 DEPAUL L. REV. 253, 255 (2006) (citations omitted).

65. Okimoto \& Wenzel, supra note 27, at 305; see also Christopher P. Reinders Folmer, Pieter T.M. Desmet, \& Willem H. Van Boom, Beyond Compensation? Examining the Role of Apologies in the Restoration of Victims' Needs in Simulated Tort Cases, 43 L. \& Hum. BeHAV. 329, 329 (2019); Abel, supra note 64, at 258 ("The fundamental goal of damage awards in the unintentional tort area is to return the plaintiff as closely as possible to his or her condition before the accident.") (citations omitted).

66. Martha Chamallas, The Architecture of Bias: Deep Structures in Tort Law, 146 U. PA. L. REV. 463, 490 (1998).

67. Id. 
for physical harm. ${ }^{68}$

The most obvious (and common) tort remedies for emotional injuries come in the form of claims for intentional or negligent infliction of emotional distress. Recovery for intentional infliction of emotional distress generally requires an individual to "intentionally or recklessly cause[] severe emotional distress" to another. ${ }^{69}$ Typically, recovery for intentional infliction of emotional distress requires more than garden variety conduct; the conduct must be unusually offensive. ${ }^{70}$ And it must be specifically intended to harm the injured party. ${ }^{71}$ As Martha Chamallas, who argues that the emphasis on physical and pecuniary damage is harmful to women, explained, "[i]n theory at least, the intentional infliction of the most trivial physical harm is a legal wrong. With respect to emotional harm, however, the law responds only to severe injuries and only if the wrongdoer is of the worst order and deliberately oversteps the bounds of common decency.",72

Recovery for negligent infliction of emotional distress is even more limited. ${ }^{73}$ In most jurisdictions, recovery is only permitted for negligent infliction of emotional distress where the injured party "can prove that the

68. Id. at 491, 503-04 (articulating that the existence of statutory caps on noneconomic damages reflects this disfavoring of non-physical, non-pecuniary harms).

69. RESTATEMENT (SECOND) OF TORTS § 46(1) (AM. LAW INST. 1965) (emphasis added).

70. See, e.g., White v. Monsanto Co., 585 So. 2d 1205, 1210 (La. 1991) ("Recognition of a cause of action for intentional infliction of emotional distress in a workplace environment has usually been limited to cases involving a pattern of deliberate, repeated harassment over a period of time.").

71. See, e.g., Standard Fruit \& Vegetable Co. v. Johnson, 985 S.W.2d 62, 68 (Tex. 1998) (requiring emotional distress to be "the intended or primary consequence of [the defendant's] conduct"); Potter v. Firestone Tire \& Rubber Co., 863 P.2d 795, 820-21 (Cal. 1993) (holding that it is not enough to show that the defendant knew his/her conduct may cause severe distress to any given person; to be liable, the defendant must have known that his/her conduct would cause severe distress to the plaintiff).

72. Chamallas, supra note 66, at 492. Moreover, "[a]lthough tortfeasors take victims as they find them physically (the 'eggshell' or 'thin skull' plaintiff rule), victims can recover emotional distress only if an objectively 'reasonable' person would suffer it. And courts impose a de minimis requirement on emotional distress (which must be severe) but not on physical injury." Abel, supra note 64 , at 307 (citations omitted).

73. Hedgepeth v. Whitman Walker Clinic, 22 A.3d 789, 795-98 (D.C. Cir. 2011) (providing an overview of the different rules across jurisdictions and expressing many of the policy concerns courts have in allowing recovery for emotional harm); Sacco v. High Country Indep. Press, Inc., 896 P.2d 411, 425 (Mont. 1995) ("A cause of action for negligent infliction of emotional distress will arise under circumstances where serious or severe emotional distress to the plaintiff was the reasonably foreseeable consequence of the defendant's negligent act or omission."); John C.P. Goldberg \& Benjamin C. Zipursky, Unrealized Torts, 88 VA. L. REV. 1625, 1667-71 (2002) (describing how emotional distress claims are currently analyzed by many courts). 
emotional trauma had physical consequences." ${ }^{\text {"74 }}$ Others limit emotional distress recovery to those who are themselves injured (the parasitic/predicate damage distinction) or who are close relatives of the injured party and who observe the injury. ${ }^{75}$

In the tort system, then, recovery for emotional harm is limited, whether that harm is "parasitic" on a claim for physical harm or is the result of one of these "independent" torts. ${ }^{76}$ These limits on emotional recovery are often justified by the need to engage in line drawing and fears of the potential for limitless liability. ${ }^{77}$ Indeed, the line-drawing in this area has been seemingly arbitrary and has resulted in disparate outcomes from state to state and case to case. ${ }^{78}$

The criminal system's focus on retributive justice and deterrence is similarly unfocused on addressing the injuries to dignity and psyche that accompany being harmed. ${ }^{79}$ Although there has been some recent movement toward restorative justice principles with apologies as one method of promoting restorative justice, such efforts have thus far been relatively limited in scope. ${ }^{80}$ Neither system has as its primary goal

74. Chamallas, supra note 66, at 492; see also R.J. v. Humana of Florida, Inc., 652 So. 2d 360, 362 (Fla. 1995) (explaining that "the requirement of a physical impact gives courts a guarantee that an injury to a plaintiff is genuine" ensuring that courts do not "open the floodgates for fictitious or speculative claims") (citations omitted); Goldberg \& Zipursky, supra note 73, at 1662-63.

75. Goldberg \& Zipursky, supra note 73, at 1671.

76. See generally Abel, supra note 64 (discussing general damages and providing examples of the often arbitrary limitations provided by various jurisdictions).

77. See Abel, supra note 64, at 303 ("Such claims would create a 'flood of litigation where the injury complained of may be easily feigned without detection, and where the damages must rest upon mere conjecture and speculation ...."”) (quoting Mitchell v. Rochester Ry. Co., 45 N.E. 354, 354-55 (N.Y. 1896), overruled by Battalla v. State, 176 N.E.2d 729 (N.Y. 1961)). These fears continue despite advances in medicine and technology that make proving mental and emotional distress more precise and accurate. Chamallas, supra note 66, at 493-94; Goldberg \& Zipursky, supra note 73, at 1670 (noting the concern that "claims of emotional distress are, as contrasted to claims of physical injury, harder to substantiate, easier to fake, and harder to value"). As Chamallas explained, "[c]oncerns about fake injuries, the hypersensitive plaintiff, and tracing cause and effect are often no more difficult in these contested contexts than in those contexts in which recovery has already been permitted. Even those commentators who are loath to extend liability tend to recognize that these old arguments about problems of proving mental injury are now 'regarded with some suspicion." Chamallas, supra note 66, at 496 (quoting Ira Mark Ellman \& Stephen D. Sugarman, Spousal Emotional Abuse as a Tort?, 55 MD. L. REV. 1268, 1298-1301 (1996)). Chamallas goes on to argue that "[t]he need to draw the line somewhere gives no guidance as to the wisdom of the current limitations." Id.

78. See, e.g., Abel, supra note 64, at 304-11 (recounting anecdotes to illustrate the arbitrariness of lines determining who is and is not entitled to damages for emotional harms).

79. Bibas \& Bierschbach, supra note 62, at 104-05, 136-37.

80. Id. at 122-26. The restorative justice practices tried by many communities - most often victim-offender mediation or family conferencing - have shown success. Id. at 131-32. As Bibas and Bierschbach explained: 
addressing these harms, ${ }^{81}$ and, likely as a consequence, neither is particularly well suited to doing so.

Even where actionable, emotional distress, like other non-physical, non-pecuniary harms, is difficult to monetize. ${ }^{82}$ Perhaps this is because these harms to dignity are largely incommensurable. ${ }^{83}$ Or perhaps this is because we have a moral or emotional aversion to monetizing those things which seem incommensurable. ${ }^{84}$ Indeed, some courts have recognized the inability of the tort system to fully compensate for emotional harms such as loss of enjoyment of life. ${ }^{85}$ And the more nebulous harms to dignity from being injured such as feeling insulted, disempowered, or humiliated ${ }^{86}$ are not addressed at all by the legal system. Besides the fact that the legal system does not generally compensate for emotional harms, there is reason

\footnotetext{
A meta-analysis of empirical studies found that victim-offender mediation and family conferencing (hereinafter "mediation") was consistently more successful than traditional criminal justice in a variety of ways: $82 \%$ of victims whose cases were handled in mediation believed that the criminal justice system was fair, versus $56 \%$ of those in court. Likewise, $91 \%$ of offenders whose cases were handled in mediation thought the criminal justice system was fair, versus $78 \%$ of those in court. The same meta-analysis found that $78 \%$ of victims in mediation were satisfied with the handling of their cases, versus $56 \%$ of victims in traditional court proceedings. Likewise, $84 \%$ of offenders in mediation were satisfied with the handling of their cases, versus $73 \%$ of offenders in court. Those in mediation are more likely to have a chance to tell their stories (94\% versus $64 \%$ of victims, and $88 \%$ versus $64 \%$ of offenders). They are also more likely to feel that their opinions were adequately considered (94\% versus $92 \%$ of victims, and $72 \%$ versus $55 \%$ of offenders). They are more likely to feel that the judge or mediator was fair in their particular case ( $88 \%$ versus $76 \%$ of victims, and $91 \%$ versus $63 \%$ of offenders). Those in mediation are more likely to feel that the outcome was fair and satisfactory (73\% versus $54 \%$ of victims, and $77 \%$ versus $67 \%$ of offenders). They are also more likely to believe that the offender was held accountable (92\% versus $71 \%$ of victims, and $82 \%$ versus $49 \%$ of offenders). In mediation, offenders are more likely to apologize (74\% versus $29 \%$ ), victims are more likely to forgive ( $43 \%$ versus $22 \%$ ), and victims are less likely to remain upset $(28 \%$ versus $57 \%)$ or fear revictimization ( $15 \%$ versus $34 \%)$.
}

Id. at 131-33 (citations omitted). This success seems especially pronounced in the juvenile offender setting: Bibas and Bierschbach concluded that mediation reduced recidivism and that those juveniles who did engage in further crime after mediation committed less severe offenses than those who experienced adjudication without mediation. Id.

81. See id. at 125-27, 136-37.

82. See Abel, supra note 64, at 291-303 (recounting anecdotes to illustrate the difficulties and variability in calculating general forms of damages).

83. See id. at 273-75 (recounting anecdotes of people who suffered injuries or losses deemed incommensurable).

84. See Chamallas, supra note 66, at 497 ("Many people recoil from reducing emotions and relationships to a dollar figure, and consider it degrading and perhaps even immoral to evaluate human life and human relationships according to commercial measures.").

85. See id. at 505.

86. Okimoto \& Wenzel, supra note 27, at 295. 
to think that it would be ineffective at doing so given the disparate outcomes related to other claims for emotional harms. ${ }^{87}$

Yet, those insults to dignity are real and felt by injured parties. Evidence suggests that compensatory justice is insufficient; the needs of injured parties extend beyond material concerns. ${ }^{88}$ Injured parties desire (and potentially expect) redress for those harms, regardless of whether the tort or criminal systems offer it. ${ }^{89}$ Indeed, anecdotes abound of individuals who received large monetary judgments but remain embittered and angry at the person (or entity) who has failed to apologize, express remorse, and repent. ${ }^{90}$ What they seek, it seems, is a "restoration of justice." $"$ Of this comes in the form of an apology. ${ }^{92}$

\section{As Okimoto and Wenzel explain:}

First, transgressions can upset the status and power balance between offenders, victims, and society as a whole. When victims interpret an injustice as a disruption of this status and power equilibrium, their status/power becomes a principal concern, relative to the offender and within the group in which the injustice occurred. Second, transgressions can violate values that victims expect to share with the offender due to their personal relationship or common membership in a group or society. When victims interpret an injustice as a threat to these shared values, the

87. See, e.g., Abel, supra note 64, at 304-11.

88. Folmer et al., supra note 65 , at 329; Okimoto \& Wenzel, supra note 27 , at 294 . Injured parties find restitution insufficient and offenders are often assigned punishments "more severe than equity standards dictate." Okimoto \& Wenzel, supra note 27, at 294 (citations omitted). One possible argument for these stronger punishments is the potential that they will deter future harmful conduct. Id. But, as Okimoto and Wenzel point out, "despite widespread use of behavior control as a justification of severe criminal penalties, there is inconsistent evidence regarding the effectiveness of punitive forms of behavior control (such as monetary penalties or incarceration) for motivating future adherence to societal rules." Id. (citations omitted).

89. Okimoto \& Wenzel, supra note 27, at 292.

90. Abel, supra note 64, at 261-66. Despite monetary awards, these individuals desired an apology, an admission of guilt, an expression of remorse, or an indication that the harming party had made changes to prevent the same harm from happening to others. Id. For example, Abel recounts the story of the father of a fourteen-year-old boy who was rendered paraplegic by a defective lap belt: despite being awarded a jury verdict of $\$ 3.3$ million, the father " "became angry because Ford refused to admit to anything .... [he] sat there three weeks through the trial. It was like they were above everybody else, even after the jury came in. Ford didn't care. They really didn't care.' His lawyers subsequently filed a petition with the United States Department of Transportation seeking to force Ford to recall 1.7 million cars." Id. at 261 (quoting Ordeal of Son's Auto Injury Spurs Father to Seek a Recall, N.Y. TIMES, Jan. 17, 1988, § 1, at 39).

91. Okimoto \& Wenzel, supra note 27, at 294 (citations omitted).

92. See Abel, supra note 64, at 262-66 (recounting anecdotes in which injured parties minimized the value of monetary compensation and instead emphasized the need for an apology, an admission of guilt, or an expression of remorse). 
validity of those values becomes a principal concern. ${ }^{93}$

They go on to argue that any response to the harm must address these symbolic concerns "in order to be considered satisfactory" by and "restore the sense of justice" of the injured party. ${ }^{94}$ Beyond the compensatory and punitive functions served by the legal system, apologies may further serve this justice-restoring function. ${ }^{95}$ Indeed, apology has been found to satisfy these nonmaterial needs, beyond what is possible through monetary compensation. ${ }^{96}$

Apologies can also address harms to dignity caused by injury anywhere on the spectrum of liability - from no legal liability through criminal liability. Indeed, many of the objections to apology protections are focused on a narrow subset of the spectrum of liability - the area in which liability is disputed such that the presence of an apology could lead a fact-finder to presume the person apologizing is liable, when, without that apology the factfinder would not come to that conclusion. ${ }^{97}$ Yet, the lack of protection for apologies discourages apologies everywhere on the spectrum.

This aspect of apologies - their ability to address non-monetary harms - may explain why at least some studies have found settlement more likely and/or settlement amounts lowered when an apology is offered. ${ }^{98}$ It may be that a party is willing to accept a (lower-thanotherwise-desired) settlement offer when paired with an apology because the apology redresses the injury to dignity, which the party would otherwise expect monetary compensation to remedy.

\section{Apologies Can Provide Litigation Efficiencies.}

To date, most legal academics evaluating evidentiary protections for apologies have focused on the judicial efficiencies that might be created by exempting apologies from evidence. In particular, most scholarly work has focused on the potential impact to the amount of litigation (meaning

93. Okimoto \& Wenzel, supra note 27, at 292.

94. Id.

95. Folmer et al., supra note 65, at 330; Okimoto \& Wenzel, supra note 27, at 310.

96. Folmer et al., supra note 65, at 338.

97. See Lucinda E. Jesson \& Peter B. Knapp, My Lawyer Told Me to Say I'm Sorry: Lawyers, Doctors, And Medical Apologies, 35 WM. MitchelL L. REV. 1410, 1429 (2009); see also Abel, supra note 64 , at 264 .

98. See, e.g., Jesson \& Knapp, supra note 97, at 1422-23 (citing Jennifer K. Robbennolt, Apologies and Legal Settlement: An Empirical Examination, 102 MiCH. L. REV. 460, 484-86 (2003)). 
the number of cases filed and the size and speed of settlements). ${ }^{99}$ This is for good reason: apologies have the ability to decrease the number of suits, the amount of settlements, and the time it takes for a matter to settle. ${ }^{100}$ For example, offering apologies during the mediation process is more likely to lead to a positive resolution. ${ }^{101}$

Jennifer Robbennolt's work has shown that full apologies, in particular, can drastically increase the propensity of individuals to accept settlement offers. ${ }^{102}$ In her study, participants were assigned to be accident victims, and, after reading an explanation of the accident, evaluated a settlement offer from the other party. ${ }^{103}$ Some of the settlement offers included no apology, others included an expression of sympathy with no acceptance of responsibility (a partial apology), and a third group of offers included expressions of sympathy and admissions of fault (a full apology). ${ }^{104}$ When no apology was offered, 52\% of accident victims said that they would "either definitely or probably accept the offer," $43 \%$ said that they would reject it, and 5\% were uncertain. ${ }^{105}$ When a full apology was provided, more hypothetical accident victims were willing to accept the settlement offer: $73 \%$ of participants were inclined to accept, and 13$14 \%$ "inclined to reject it or remain[ed] unsure."106 Partial apologies tended to create uncertainty for participants: "only $35 \%$ of participants were inclined to accept the offer, $25 \%$ were inclined to reject it, and 40\%" remained undecided as to what course of action to take. ${ }^{107}$

Indeed, many scholars have recognized that apologies can be helpful in preventing lengthy legal battles. ${ }^{108}$ And some studies have suggested

99. See generally Folmer et al., supra note 65, at 329-31 (discussing several studies regarding effects of apologies in tort litigation).

100. See infra notes 101-12 and accompanying text.

101. Mandeep K. Dhami, Offer and Acceptance of Apology in Victim-Offender Mediation, 20 CRitical CRiminology 45, 55-57 (2012).

102. See generally Robbennolt, supra note 98.

103. Id. at 484 .

104. Id. at $484-86$.

105. Id. at $485-86$.

106. Id. at 486

107. Id. The conclusion that partial apologies created uncertainty is noteworthy because most states that protect apologies protect only partial apologies. See infra notes 128-32 and accompanying text. Given the conclusion of Robbennolt's study, it seems society may be losing much of the potential efficiency value of protecting apologies by structuring its apology protections in this way.

108. Helmreich, supra note 3, at 574 (describing various sources that suggest apologizing could be "legally advantageous," but noting that "the empirical research is still at an early stage. . . [and] it relies heavily on reactions to hypothetical scenarios"). 
that early apologies can help prevent litigation altogether. ${ }^{109}$ For example, in a British study many plaintiffs "who sued their doctors said they would not have done so had they had received an apology and an explanation" from the doctor. ${ }^{110}$ Similarly, Max Bolstad, in his work comparing apologies, litigation, and culture in the United States and Japan, found significant benefits of apologies in mediation and noted that apologies can both loosen stalled negotiations and sometimes prevent impasse in the first place. ${ }^{111}$

Consistent with these studies, the University of Michigan Health Service (UMHS) found that its introduction of a program requiring healthcare professionals to apologize to patients who complained about being injured in UHMS's care impacted both per-case payments and settlement time: per-case payments decreased by $47 \%$ and settlement time decreased from twenty to six months after the program was introduced. ${ }^{112}$ Indeed, one critique of apology-protection rules and statutes is that apologies could potentially encourage injured parties to agree to settle too quickly and easily, for too little in the way of compensation. ${ }^{113}$

While efficiencies in litigation are certainly a laudable goal, and while a rule exempting apologies from evidence is likely to increase litigation efficiencies, in addition to providing the individual and societal benefits discussed above in Part II.A, focusing exclusively on this aspect of apologies misses a key point: most apologies, most of the time, are not probative of anything other than someone's personal feelings of remorse for being involved in the harm of another.

\section{The CURRENT StATE OF PROTECTION FOR APOLOGIES}

Apologies currently receive no protection under the Federal Rules of Evidence and receive spotty protection by the various states. Because apologies can be used in litigation in most jurisdictions, ${ }^{114}$ lawyers

\footnotetext{
109. Id.

110. Id. (citations omitted).

111. Max Bolstad, Learning from Japan: The Case for Increased Use of Apology in Mediation, 48 Clev. ST. L. REV. 545, 569-70 (2000).

112. Helmreich, supra note 3, at 574.

113. Yonathan A. Arbel \& Yotam Kaplan, Tort Reform Through the Back Door: A Critique of Law and Apologies, 90 S. CAL. L. REV. 1199, 1233-34 (2017); see also Abel, supra note 64, at 260 (reporting one such anecdote: a widow "settled for millions less than several lawyers estimated she could have won at trial because" the insurance adjuster was kind and helpful).

114. Bolstad, supra note 111, at 565 ("Perhaps nothing discourages the use of apology in the United States today more than the fear of liability.”).
} 
routinely advise their clients not to apologize. ${ }^{115}$ The Advisory Committee to the drafting of the Federal Rules of Evidence recognized that by admitting evidence of statements or conduct, those statements and conduct are effectively discouraged. ${ }^{116}$ Indeed, they relied on precisely this fact in excluding evidence of subsequent remedial measures and offers to pay medical expenses. ${ }^{117}$ Attorney-client privilege protections are based on this same assumption: that statements are less likely to be made at all when those statements are admissible. Or phrased another way, one way to encourage a speaker to make a statement is to ensure that the statement cannot be admitted against the speaker in court. Apologies are no different: "the tendency to admit apologies into evidence seems to deter the practice of apologizing." 118

\section{A. Apologies Are Not Protected Under the Current Federal Rules of Evidence.}

Generally, in federal court all relevant evidence is admissible, unless the Constitution, federal statutes, rules prescribed by the Supreme Court, or the Rules of Evidence themselves provide otherwise. ${ }^{119}$ But courts may exclude otherwise relevant evidence if its probative value is substantially outweighed by the danger of unfair prejudice resulting from its admission. ${ }^{120}$ Relevant evidence is evidence that "has any tendency to make a fact [of consequence in determining the action] more or less probable than it would be without the evidence ...."121

Under the current Rules, apologies get no special treatment. Apologies, like all evidence not categorically excluded, are subject to a case-by-case determination of relevance and admissibility-which generally means a case-by-case weighing of the probative value of the evidence against the likelihood that the evidence, if introduced, would result in unfair prejudice. ${ }^{122}$ Apologies are out of court statements offered for the truth of the matter asserted, and are, thus, classic hearsay.

\footnotetext{
115. See Abel, supra note 64, at 264 ("[D]efense lawyers strongly discourage clients from accepting any responsibility."); Farmer, supra note 3, at 249.

116. See infra Section III.D.

117. See infra Section III.D.

118. Helmreich, supra note 3, at 573.

119. FED. R. EVID. 402.

120. FED. R. EVID. 403.

121. FED. R. EVID. 401.

122. See FED. R. EVID. 403.
} 
Nonetheless, because they are generally viewed to be statements against a party's interest, they are not excluded categorically under the current rules. $^{123}$

As discussed in Part IV below, given the findings of social science researchers, the balancing of probative value and the risk of unfair prejudice should result in a conclusion by courts that an apology is not admissible evidence. Yet courts, like jurors, tend to assume that apologies are probative of fault (even if only moral fault), and therefore are probative of legal liability. As such, courts tend to admit apologies as evidence of liability.

\section{B. State Rules, Where They Exist, Largely Protect Only Partial Apologies.}

Though the Federal Rules of Evidence do not include special treatment for apologies, a number of states have adopted rules or statutes limiting their admissibility in state courts. ${ }^{124}$ Massachusetts was the first

123. FeD. R. Evid. 804(b)(3). See also Jonathan R. Cohen, Legislating Apology: The Pros and Cons, 70 U. CIN. L. Rev. 819, 824-25 (2002). They might also come in under the excited utterance exception to the hearsay rule. See FED. R. EvID. 803(2) ("The following are not excluded by the rule against hearsay, regardless of whether the declarant is available as a witness: . . Excited Utterance. A statement relating to a startling event or condition, made while the declarant was under the stress of excitement that it caused.").

124. See Michael B. Runnels, Apologies All Around: Advocating Federal Protection for the Full Apology in Civil Cases, 46 SAN DIEGo L. REv. 137, 151 n.70 (2009) (listing "thirty-five statesconsistent with their characterization by Justice Brandeis as laboratories of democracy - [that] have enacted statutes designed to encourage apologies by providing evidentiary protections....") (footnotes omitted). The following state statutes provide some form of apology protection: ALASKA STAT. § 09.55.544 (West, Westlaw through Ch. 32 of 2020 Second Reg. Sess. of 31st Leg.); ARIZ. Rev. Stat. AnN. § 12-2605 (West, Westlaw through Second Reg. Sess. of 54th Leg.); CAL. Evid. CODE § 1160(a) (West, Westlaw through Ch. 302 of 2020 Reg. Sess.); Colo. Rev. STAT. ANN. § 1325-135(1) (West, Westlaw through all Legis. of 2020 Reg. Sess.); Conn. Gen. Stat. AnN. § 52$184 d$ (b) (West, Westlaw through all enactments of 2020 Reg. Sess. \& 2020 July Spec. Sess.); D.C. Code ANN. § 16-2841 (West, Westlaw through Aug. 14, 2020); Del. Code ANN. tit. 10, § 4318(b) (West, Westlaw through Ch. 292 of 150th Gen. Assemb.); Fla. Stat. ANN. § 90.4026(2) (West, Westlaw through 2020 Second Reg. Sess. of 26th Leg.); GA. CoDE ANN. § 24-3-37.1 (West, Westlaw through Laws 2020, Act 545); HAW. Rev. StAT. AnN. § 626-1 (West, Westlaw through Act 15 of 2020 Reg. Sess.); IdAHo Code ANN. § 9-207(1) (West, Westlaw through 2020 Second Reg. \& First Extraordinary Sess. of 65th Idaho Leg.); IND. CODE ANN. § 34-43.5-1-4 (West, Westlaw through all Legis. of 2020 Second Reg. Sess. of 121st Gen. Assemb.); IowA CODE ANN. § 622.31 (West, Westlaw through 2020 Reg. Sess.); LA. CIV. CODE ANN. art. 13:3715.5 (West, Westlaw through 2019 Reg. Sess.); ME. Rev. Stat. AnN. tit. 24, § 2907(2) (West, Westlaw through 2019 Second Reg. Sess. of 129th Leg.); MD. Code ANN., CTS. \& JUD. PrOC. § 10-920 (West, Westlaw through 2020 Reg. Sess. of Gen. Assemb.); MASs. Gen. Laws ANN. Ch. 233, § 23D (West, Westlaw through Ch. 176 of 2020 Second Ann. Sess.); Mich. Comp. LaWs $\$ 600.2155$ (West, Westlaw through P.A.2020, No. 164, of 
state to adopt such limitations in 1986 after a state senator, who had been angry when the motorist who accidentally killed his daughter failed to apologize, learned that the motorist had not done so because it would "have constituted an admission in the litigation surrounding the girl's death." ${ }^{25}$ After the senator's retirement, the legislature adopted a bill presented by the senator and his successor that provided a "safe harbor" for those who wanted to apologize. ${ }^{126}$ Several other states followed suit. ${ }^{127}$

In all, approximately forty states plus the District of Columbia have adopted some form of apology protection. ${ }^{128}$ But the extent of that protection varies widely. ${ }^{129}$ Some protect only partial apologies. ${ }^{130}$ Those jurisdictions, roughly thirty, typically protect expressions of sympathy or

2020 Reg. Sess., 100th Leg.); Mo. Rev. STAT. § 538.229 (West, Westlaw through West ID No. 26 of 2020 Second Reg. Sess. of 100th Gen. Assemb.); Mont. CoDE ANN. § 26-1-814 (West, Westlaw through 2019 Sess.); NEB. REV. STAT. ANN. § 27-1201(1) (West, Westlaw through Legis. effective Oct. 1, 2020, of Second Reg. Sess. of 106th Leg.); N.H. REV. STAT. ANN. § 507-E:4 (West, Westlaw through Ch. 39 of 2020 Reg. Sess.); N.C. GEN. STAT. ANN. § 8C-1, Rule 413 (West, Westlaw through S.L. 2020-74 of 2020 Reg. Sess. of Gen. Assemb.); Ohio Rev. Code ANN. § 2317.43(A) (West, Westlaw through File 45 of 133rd Gen. Assemb.); OKLA. STAT. tit. 63, § 1-1708.1H(A) (West, Westlaw through Sept. 1, 2020 of Second Reg. Sess. of 57th Leg.); OR. REV. STAT. ANN. § 677.082 (West, Westlaw through 2020 Reg. Sess. of 80th Legis. Assemb.); S.C. CODE ANN. § 19-1-190(B) (West, Westlaw through 2020 Act No. 142); S.D. CodifIED LAws § 19-12-14 (West, Westlaw through 2020 Sess. Laws); TenN. Code ANN. § 409.1(a) (West, Westlaw through Aug. 15, 2020); TeX. Civ. PRAC. \& ReM. Code ANN. § 18.061(a)(1) (West, Westlaw through 2019 Reg. Sess. of 86th Leg.); Utah Code AnN. § 78B-3-422(2) (West, Westlaw through 2020 Sixth Spec. Sess.); Vt. Stat. AnN. tit. 12, $\$ 1912$ (West, Westlaw through Acts 1-130, 132-148, 150, M-1-M-11 of Adjourned Sess. of 2019-2020 Vt. Gen. Assemb.); VA. CODE ANN. § 8.01-52.1 (West, Westlaw through 2020 Reg. Sess. \& 2020 Spec. Sess. I, c. 1); WASH. REV. CODE ANN. § 5.64.010(2) (West, Westlaw through 2020 Reg. Sess.); W. VA. CODE ANN. § 55-7-11a(b)(1) (West, Westlaw through Legis. of 2020 Reg. Sess.); WIS. STAT. AnN. § 904.14 (West, Westlaw through 2019 Act 186); Wyo. STAT. ANN. § 1-1-130(a) (West, Westlaw through 2020 Budget Sess. \& Chs. 1-3 of 2020 Spec. Sess.). Illinois previously had a statute protecting sympathetic gestures, 735 ILL. COMP. STAT. ANN. 5/8-1901 (West, Westlaw through P.A. 101-651), but the statute was declared unconstitutional by the Illinois Supreme Court in 2010. See Lebron v. Gottlieb Memorial Hosp., 930 N.E.2d 895 (Ill. 2010).

125. Lee Taft, Apology Subverted: The Commodification of Apology, 109 YALE L.J. 1135, 1151 (2000).

126. Id.

127. See supra note 124 .

128. See supra note 124; see also Farmer, supra note 3, at 252.

129. See Farmer, supra note 3, at 252-54.

130. See, e.g., TEX. CIV. PRAC. \& REM. CODE ANN. § 18.061(a)(1) (“A court in a civil action may not admit a communication that[] . . . expresses sympathy or a general sense of benevolence relating to the pain, suffering, or death of an individual involved in an accident ...."); FLA. STAT. ANN. § 90.4026(2) (same); N.H. REV. STAT. ANN. § 507-E:4 (same); see also Farmer, supra note 3, at 25354; Helmreich, supra note 3, at 569 (explaining that partial apology jurisdictions generally protect only expressions of good will, such as sympathy and benevolence but "deny protection to expressions of remorse, guilt, and self-criticism"). 
benevolence but view admissions of fault as admissible evidence. ${ }^{131}$ And eighteen of those that protect partial apologies do so only in the medical malpractice liability setting. ${ }^{132}$ The remaining eight offer protection for full apologies - typically defined as statements expressing both sympathy or benevolence and remorse, guilt, or self-criticism-but each of those jurisdictions offer protection only in the medical malpractice liability setting. ${ }^{133}$ No state currently offers general protection for full apologies outside of the medical malpractice context, and nearly a dozen offer no statutory or evidentiary protection at all for apologies. ${ }^{134}$

As an aside, almost every province in Canada has adopted laws protecting apologies in civil cases. ${ }^{135}$ These apology-protections tend to be broad and to protect statements of sympathy or regret that "admit or imply an admission of fault in connection with [any] matter ...."136 In other words, Canadian laws tend to protect full apologies, including admissions of fault, not just expressions of regret or sympathy. ${ }^{137}$ While many of the same objections and skepticisms have been raised related to Canada's laws, ultimately, Canadian lawmakers determined the policy reasons for promoting apologies were sufficiently important to favor their adoption. ${ }^{138}$

\section{Apologies Are Not Generally Probative of Legal FAult.}

Although the current state of the law does not encourage apologies, as discussed above, there are real benefits of apologies for the injured party,

131. See, e.g., Mo. Rev. Stat. § 538.229; Tex. Civ. Prac. \& Rem. Code Ann. § 18.061(a)(1); see also Farmer, supra note 3, at 252-53 (citing Edward A. Dauer, Apology in the Aftermath of Injury: Colorado's "I'm Sorry” Law, 34 Colo. LAw. 47, 47 (2005)); see also id. at 245 n.15 (listing state statutes that protect apologies in medical malpractice and other contexts, as well as cases that have interpreted several of those statutes).

132. See, e.g., OHIO Rev. Code AnN. § 2317.43(A); UtAH Code ANN. § 78B-3-422(2); IdAHO CODE ANN. § 9-207(1).

133. See, e.g., Colo. Rev. StAT. ANN. § 13-25-135(1); see also Farmer, supra note 3, at 246 n.15 (listing further statutes that protect full apologies, but only in the medical malpractice context).

134. Farmer, supra note 3, at 253-55.

135. See Robyn Carroll, Christopher To, Marc Unger, Apology Legislation and its Implications for International Dispute Resolution, 9 DISP. RESOL. INT'L 115, 116 n.5 (2015).

136. See Uniform Apology Act (2007), UNIF. LAW CONF. OF CAN., https://www.ulcc.ca/en/home/119-josetta-1-en-gb/uniform-actsa/apology-actpresentation-dexcuses/1425-apology-act-2 [https://perma.cc/UG4L-6TYV].

137. Id.

138. See Russell J. Getz, Policy Paper on Apology Legislation, UnIF. LaW Conf. OF CAN., (Sept. 9-13, 2007) https://www.ulcc.ca/en/home/119-josetta-1-en-gb/uniform-actsa/apology-actpresentation-dexcuses/1128-policy-paper-on-apology-legislation [https://perma.cc/7L3A-FEGA]. 
the apologizer, and society as a whole. This Article does not argue, however, that these benefits alone justify federal protection for apologies. If apologies provided perfect evidence of liability, these benefits might be outweighed by the probative value of the apology. But apologies do not provide perfect evidence of legal liability. In fact, this Article argues that because of the psychological, social, and moral underpinning of apologies, they provide little to no evidence of legal liability. As such, this Article argues that a Federal Rule of Evidence protecting apologies is warranted because apologies are not, as a general matter, evidence of legal fault.

We, as lawyers, judges, and juries, assume that people feel guilt and apologize when they are to blame for harming another. Indeed, that is the justification for admitting apologies as evidence in any circumstance: people do not apologize for no reason; if he apologized there must be some reason to think he is at fault; indeed, he must think he is at fault. Yet the reality is that the relationship among apologies, guilt, and blameworthiness is not so simple. Neither guilt nor blameworthiness are necessary ingredients to apologies: ${ }^{139}$ It is common to feel guilt in the absence of blameworthiness, and it is common to apologize in the presence (and absence) of feelings of guilt. ${ }^{140}$ People $d o$ apologize for no reason. Indeed, feeling guilt and offering an apology regardless of fault is morally, psychologically, and socially appropriate. ${ }^{141}$

And in fact, it is intuitive that there are reasons one might apologize that have nothing to do with legal fault. It is similarly obvious that one might expect an apology for wrongs that are unrelated to legal fault. For example, one might apologize because she makes an assessment that she has violated a social or cultural norm- "I'm sorry I'm late," "I'm sorry I missed your call." Apologies can be expressions of sympathy or empathy-“I'm sorry your loved one died," "I'm sorry you were not accepted by your first-choice college." One might apologize because he believes he has violated a personal norm or standard, for example avoiding harm, or because he had involvement in another's negative experience"I'm sorry I got the last available appointment." And apologies sometimes reflect a combination of these perspectives-“'I'm sorry we can't offer you a job." Gender and culture also impact the frequency of and reasons for apologies. For example, it is widely accepted that women apologize more frequently and for less serious offenses than men. And apologies are more

\footnotetext{
139. See Baumeister et al., supra note 30 , at 258-60.

140. Id.

141. Id. at 260; Helmreich, supra note 3, at 582.
} 
often delivered in some cultural contexts than others. For example, Americans apologize less frequently than Japanese; indeed, the Japanese practice is to apologize even when one thinks the other party is at fault. ${ }^{142}$ What is clear, though, is that an apology, even one expressing remorse, guilt, or self-criticism, is not always probative of legal liability.

Ultimately, three categories of research related to apologies illustrate their lack of probative value. First, guilt and the associated compulsion to apologize is morally appropriate even in the absence of fault. Second, psychological research confirms that apologies are not necessarily linked with blameworthiness. And third, societal expectations of apologies in the absence of fault coupled with gender and culture differences in apology practices belie their use as evidence of legal liability.

\section{A. Apologies in the Absence of Fault are Supported by an Analysis of Moral Propriety.}

As a philosophical matter, a self-critical stance, and consequently a self-critical statement as part of an apology, is an appropriate response to harming others, even when one's conduct was both morally and legally blameless. ${ }^{143}$ Jeffrey Helmreich reasons that "people have reason to be self-critical of the harms they blamelessly caused" because "harming others, even blamelessly, constitutes a misuse or misfire of one's considerable efforts to avoid doing so, efforts in whose success moral agents are deeply invested." 144 As such, "[e]ven purely non-culpable injurers have reason to take the stance expressed by remarks such as 'I really messed up,' or 'I did something horrible."'145 Such self-critical expressions, Helmreich argues, "do[] not imply legal or moral culpability any more than [they] impl[y] innocence ...."146

Helmreich provides the example used by Bernard Williams, a prominent philosopher:

[A] truck driver, who blamelessly runs over a child who had quickly crawled into the street, hidden from view. Although everyone on the scene, including the handful of spectators

\footnotetext{
142. See Brooks et al., supra note 43, at 467 (citing William W. Maddux, Peter H. Kim, Tetsushi Okumura, \& Jeanne M. Brett, Cultural Differences in the Function and Meaning of Apologies, 16 INT'L NEGOT. 405 (2011)).

143. Helmreich, supra note 3, at 582.

144. Id. at 581

145. Id.

146. Id. at 582 .
} 
gathered at the roadside, properly regards the fatal accident as tragic and horrible, the driver alone feels what Williams calls "agent regret." He feels a special sort of negative reaction on account of being the one who inflicted the damage, even if he did so blamelessly. And, Williams suggests [and Helmreich's analysis confirms], he should react that way. ${ }^{147}$

Helmreich analogizes the tension between serious efforts to avoid harming others and the knowledge that one has done so to other instances in which one is actively invested in avoiding an outcome that comes to pass, like being self-critical after missing a shot in a basketball game in which one is invested, or being self-critical for messing up a room that one was invested in cleaning. ${ }^{148}$ In the same way that a self-critical stance is appropriate in those circumstances because of one's active investment in the opposite outcome, it is appropriate when inadvertently harming another, because of the person's active investment in avoiding that outcome. ${ }^{149}$ In other words, "I'm sorry I messed up" is as appropriate when one blamelessly harms another as it is when one culpably harms another, and so the apology itself should not be viewed as evidence of culpability. ${ }^{150}$

Helmreich's analysis also supports the notion that a self-critical stance is appropriate when one blamelessly violates social and cultural norms, assuming that the actor is invested in not violating those norms. For example, a self-critical stance (and apology) is appropriate and expected when someone is late for an appointment, even when late for reasons beyond his or her control (for example, witnessing an accident on the way to the appointment). And in those situations where an apology is culturally or socially expected, failing to follow that norm can create a separate harm.

Jonathan Cohen discusses this concept using the example of a hit-andrun accident. He explains that " $\mathrm{t}] \mathrm{h}$ he problem with 'hit-and-run' driving is not just the colliding ... but with the fleeing, which is usually intentional." " When one who causes inadvertent harm "ignores it, acting as though nothing untoward had happened," making "no effort to redress or apologize for it," that behavior is independently harmful because "it

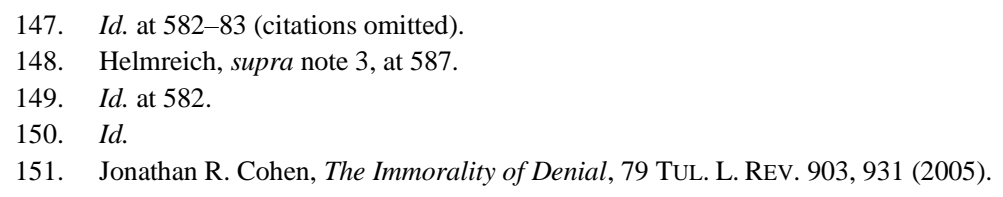


treats the victim as though one is free to harm her in that way." 152 "And this treatment, or mistreatment, is objectively insulting and disrespectful, even if the initial harmful behavior was not." 153

But conduct need not be morally blameless for self-critical statements about it to lack probative value. Self-critical statements and full apologies do not imply legal culpability any more when the conduct at issue is morally blameworthy than when it is morally blameless, or where the moral blameworthiness of the conduct is murky.

As Helmreich explains:

Negligence, for example, means different, though related, things to law and morality. Legal negligence, roughly, involves behavior that can reasonably be expected to cause harm, whatever the actual expectations or intentions of the agent involved. One can, however, be morally blameless while being, at the same time, incorrigibly inept at living up to the objective standards set by tort law against negligence. ${ }^{154}$

The reverse is also true: one may be a scoundrel who intends to cause harm to everyone he meets, but nonetheless manages to live up to the objective standards set by tort law.

Imagine a doctor who perfectly, non-negligently follows the standard of care for his terminally ill patient, but who knows about an experimental treatment that has led to shockingly successful outcomes in cases exactly like his patient's with no notable side effects. If the doctor makes no effort to obtain the experimental treatment for the patient and the patient dies, the doctor could appropriately feel self-critical for his conduct. One might argue that he is morally blameworthy for his patient's death, and a full apology including a statement of remorse for failing to obtain the experimental treatment would be appropriate. But this statement, while arguably reflective of moral culpability, would, like self-critical statements made after blameless harms, be non-probative of legal culpability.

Other examples of situations where conduct may not be entirely morally blameless but is nonetheless completely lawful also exist - the owner of a highly lucrative business is perfectly within the law to pay his employees minimum wage so that he can pad his pockets at their expense,

152. Helmreich, supra note 3, at 600 .

153. Id. The law, of course, imposes liability for this harm to dignity only in specific and typically egregious circumstances, such as for the intentional infliction of emotional distress. Despite this lack of legal harm, a self-critical stance and apology would be appropriate to address the dignity harm.

154. Id. at 582 . 
but the moral merits of that decision would be suspect. Self-critical apologies, i.e., full apologies, are similarly appropriate and similarly nonprobative of any legal question in situations where lawful harm has occurred.

For example, in their article on designing amends for lawful civilian casualties, Wexler and Robbennolt recognize that "in the context of the military's lawful killing of civilians, neither the desire for, nor the offering of amends, is necessarily grounded in any legal claim." ${ }^{55}$ Yet, they nonetheless go on to propose a system for making amends, including for providing apologies, where the military lawfully kills civilians. ${ }^{156}$ They do so because apologies benefit both those who harm and those who are harmed, even where the harm was entirely lawful, and because there are often cultural expectations for apologies when individuals are killed, even lawfully. ${ }^{157}$ Another example of lawful conduct that may nevertheless merit both a self-critical stance and a full apology is that of justified police shootings. Like in the lawful-civilian-casualties context, a police officer may be fully justified in the use of force against an individual, but may nonetheless adopt a self-critical stance based on the injury she legally caused, particularly where she learns after the fact that while legally justified, her use of force may have been unnecessary. Offering an apology under such circumstances could benefit both the officer and the family of the deceased individual.

The fact that remorse, regret, and self-critical statements appropriately follow conduct that is morally and legally blameless and conduct that is lawful but morally suspect confirms that those feelings and statements should not be taken as evidence of legal liability.

\section{B. Disentangling Apology, Guilt, and Fault using a Psychological Perspective.}

While sometimes related to blameworthiness, guilt is often felt when an individual has no ability to control the situation or when an individual has done nothing wrong. In other words, feelings of blameworthiness can lead to feelings of guilt, ${ }^{158}$ but guilt also occurs in the absence of

\footnotetext{
155. Wexler \& Robbennolt, supra note 25, at 149 (emphasis added).

156. Id.

157. Id. at 149-50 (recognizing "demand-side and supply-side" reasons for designing a system of amends for lawful civilian casualties).

158. Baumeister et al., supra note 30, at 262 ("Intentionality and responsibility are not prerequisites for guilt, but some evidence does suggest that they increase guilt.").
} 
transgression. ${ }^{159}$ Similarly, while individuals may apologize when they feel guilt, apologies often occur in the absence of guilt. ${ }^{160}$

"Guilt motivates people to apologize, to attempt to make amends, to try to repair damage to relationships, to confess and seek forgiveness, and to change their behavior so as to be more pleasing and satisfactory to relationship partners." 161 Adults tend to assume that guilt is related to blameworthiness (they "consistently act as if guilt depends heavily on intrapsychic factors such as self-appraisal, controllable decisions, and malicious intent."). ${ }^{162}$ But, "[p]eople's beliefs about guilt may, of course, differ substantially from the actual phenomena and causes of guilt." 163 Indeed, there is ample evidence that guilt occurs frequently in the absence of transgression; ${ }^{164}$ "culpability is not required to experience feelings of guilt."165

Social science research confirms that people feel guilty in many circumstances unrelated to legal fault. For example, people feel guilty "when they observe others suffering from an undesirable circumstance, even when the observer is blameless." 166 They "feel guilty when they hurt, neglect, or disappoint others and when they benefit unfairly vis-à-vis others or at others' expense."167 They are apt to "feel guilty when they suffer less or benefit more than others do"-as, for example, when they are overpaid in comparison to others. ${ }^{168}$ Individuals "also feel guilty when they hurt someone unintentionally or when another person is seen as ultimately responsible for the hurt that they inflict on him or her"-as, for example, "in the case of unrequited love" where individuals often feel guilty for rejecting another's romantic overtures. ${ }^{169}$ Ultimately, guilt may arise whenever there are perceived inequities within a relationship or when

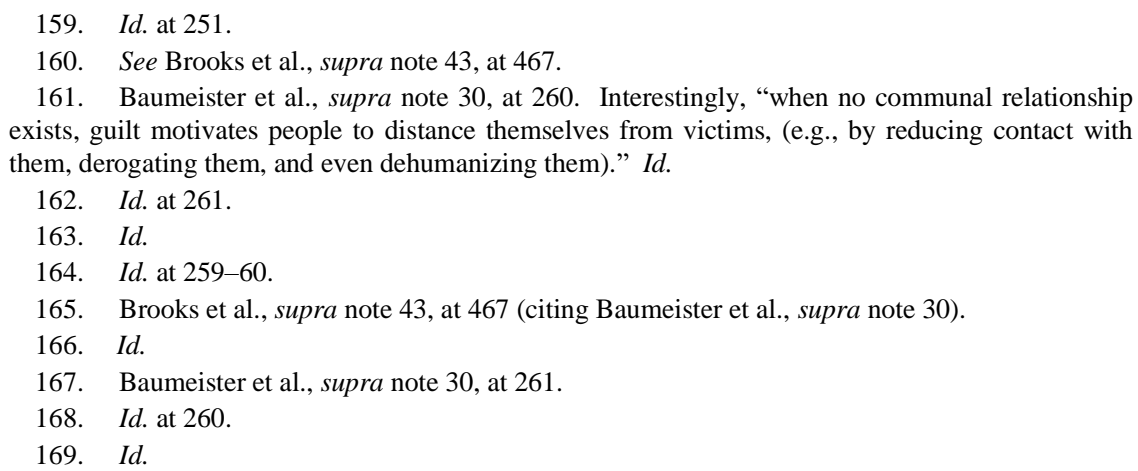


one is involved in circumstances that have a negative outcome. ${ }^{170}$ In other words, feelings of guilt can occur without committing any transgression, and guilt is often felt in the presence of an injury regardless of blameworthiness.

Guilt is related to the propensity to search for the cause of negative outcomes by imagining counterfactual circumstances. ${ }^{171}$ People "are naturally drawn to search for the causes of events, particularly unexpected events, that occur in the course of day-to-day life." ${ }^{172}$ So, when things go wrong, the natural human inclination is to engage in counterfactual thinking - that is, to reflect on what happened and imagine how the outcome might have been changed in some aspect if the situation or their behavior had been different. ${ }^{173}$ This "mental simulation of alternative outcomes appears to guide individuals' attributions about the causes of actual outcomes." 174 In other words, counterfactual thinking leads people to draw a causal connection between their choices and the negative outcome or to attribute blame to themselves (e.g. "if only I had taken a different road home, I wouldn't have been in that car accident"). ${ }^{175}$

Several studies have found that people tend to feel the most regret over negative outcomes that are connected to an action, rather than inaction. ${ }^{176}$ Generally, "people regret actions leading to negative outcomes more than they do inactions leading to the same negative outcomes."177 Feelings of regret are also shaped by societal expectations. ${ }^{178}$ "Norm theory" argues that the degree to which one experiences regret is tied to the extent to which one's conduct conforms to or diverges from expected social behavior:

170. See id. at 262; Gilad Feldman \& Dolores Albarracín, Norm Theory and the Action-Effect: The Role of Social Norms in Regret Following Action and Inaction, 69 J. EXPERIMENTAL SOC. PSYCH. 111, 111-12 (2017).

171. Feldman \& Albarracín, supra note 170, at 112.

172. Paula M. Niedenthal, June Tangney, \& Igor Gavanski, "If Only I Weren't” Versus "If Only I Hadn 't": Distinguishing Shame and Guilt in Counterfactual Thinking, 67 J. PERSONALITY \& SOC. PSYCH. 585, 585 (1994) (citation omitted). Indeed, "one way people strive to maintain control over their environment is to ascribe cause to events." Keith D. Markman, Igor Gavanski, Steven J. Sherman, \& Matthew N. McMullen, The Impact of Perceived Control on the Imagination of Better and Worse Possible Worlds, 21 PERSONALITY \& SOC. PSYCH. BulL. 588, 594 (1995).

173. Niedenthal et al., supra note 172, at 585; see Markman et al., supra note 172, at 588-89.

174. Niedenthal et al., supra note 172, at 585 (citation omitted).

175. See Markman et al., supra note 172, at 588.

176. Feldman \& Albarracín, supra note 170, at 111-12.

177. Id. at 111.

178. Id. at $112-13$. 
For example, the decision to take a certain road from point $\mathrm{A}$ to point $\mathrm{B}$ is evaluated in regards to whether taking this road deviates from one's typical behavior. If taking a certain road is an unusual behavior and something bad happens, then the negative outcome would elicit more counterfactual thought of what might have been and hence higher likelihood for regret, but if a chosen road is perceived as normal for the person then there is lower likelihood for counterfactual thinking and regret. To act consistently with normal and accepted behavior reflects a more careful and justified decision process, which affects the degree to which the involved actor is held accountable when events turn bad and also the degree to which the person would feel bad and regretful about the decision. ${ }^{179}$

Counterfactual thinking is highly linked to feelings of guilt and selfblame; indeed, people often attribute blame to themselves following unfortunate events and engage in counterfactual thinking that amplifies feelings of guilt or shame. ${ }^{180}$ Particularly where one believes that a change in his actions could have changed the outcome, guilt can be magnified. ${ }^{181}$ Indeed, in The Impact of Perceived Control on the Imagination of Better and Worse Possible Worlds, the authors found perception of control (not actual control) to be a central factor in determining whether people engaged in counterfactual thinking. ${ }^{182}$ This interaction is also apt to be circular: perceived control increases the rate of counterfactual thinking, and through the process of counterfactual thinking, people retrospectively exaggerate their sense of control over the past events, attributing more blame for the outcome to themselves. ${ }^{183}$

By engaging in counterfactual thinking, people often draw an erroneous causal connection between their own actions and the negative outcome. ${ }^{184}$ For example, a police officer who shot a suspect but had a lawful basis for the use of deadly force might imagine other courses of

179. Id. at 112 (citations omitted).

180. See Niedenthal et al., supra note 172, at 585-88; Barbara A. Spellman \& David R. Mandel, When Possibility Informs Reality: Counterfactual Thinking as a Cue to Causality, 8 CURRENT DIRECTIONS PSYCH. SCI. 120, 120-21 (1999) ("Counterfactual thinking can amplify feelings of regret, distress and self-blame, and shame and guilt ....").

181. See Markman et al., supra note 172, at 589 ("Controllable actions by the self may be especially mutable. It should be easier to imagine oneself having made a different behavioral decision than to imagine an alternative in the behavior of another person or change in a situational factor. This is in part due to the tendency of people to attend closely to their own actions and in part due to the fact that when people make a conscious choice (e.g., which tennis shot to try, which job to take), they often consider alternative actions prior to the actual decision.")) (citations omitted).

182. Id. at 593-94.

183. Id.

184. Niedenthal et al., supra note 172, at 585-86. 
action that could have resolved the situation, which leads her to attribute fault or blame for the outcome to her own actions. ${ }^{185}$ This use of counterfactuals and attribution of fault reflects the psychological impetus for the morally appropriate self-critical stance discussed above in Part IV.A.

Though counterfactual thinking can lead people to draw an attribution connection between their actions and the negative outcome, counterfactual thinking (and the feelings of guilt that flow from it) provides information about, at most, but-for causation (e.g. if the railroad employee hadn't attempted to help the passenger carrying fireworks onto the train, ${ }^{186}$ the fireworks never would have exploded, and Mrs. Palsgraf never would have been injured by the nearby equipment that fell on her when they did). ${ }^{187}$ Indeed, even if counterfactual thinking provided perfect information about the facts underlying an incident-it does not-treating an apology resulting from a counterfactual as evidence of legal blameworthiness presumes that the average person is well-positioned to speak to her legal liability. The entire legal profession is built on the premise that the determination of legal liability is not so simple; any first-year law student could attest to the complicated nature of such determinations.

Barbara A. Spellman, of the University of Virginia, and David R. Mandel, of the University of Hertfordshire, offer an example of the effect of counterfactual thinking in the legal context separate from the impact of apologies:

185. Recall the example of the truck driver who blamelessly runs over the child. See Helmreich, supra note 3 , at 583. His counterfactual thinking would almost certainly be rife with things he could have done differently to avoid the accident. That counterfactual thinking, the feeling of guilt and regret that flow from it, and the causal connection drawn from the truck driver do not actually provide any evidence that he is legally blameworthy.

186. Or if he had not gone to work that day, or if Mrs. Palsgraf had chosen a different train or had been standing in a different place on the platform, or if the passenger had gotten to the train sooner, or had not been carrying a box of fireworks, and so on. See Markman et al., supra note 172, at 59394 (noting the same event can often elicit very different counterfactuals). In Mrs. Palsgraf's case (as in all circumstances) the list of possible counterfactuals could continue indefinitely.

187. See Palsgraf v. Long Island R. Co., 162 N.E. 99, 99-100 (N.Y. 1928). The plaintiff, Helen Palsgraf, was injured after a piece of equipment fell on her while she was waiting on a train platform. $I d$. at 99 . A passenger nearby had been rushing to board a train that was leaving the station. $I d$. The passenger was carrying an unmarked box that contained fireworks. Id. As he attempted to board, a guard on the train reached to pull him onto the car, while another guard came from behind to boost him up. Id. This caused the passenger to drop the box, which caused the fireworks to go off, which caused the equipment to fall on Mrs. Palsgraf. Id. The shock from the accident caused Mrs. Palsgraf to develop a speaking disorder. Janeen Kerper, Creative Problem Solving vs. the Case Method: A Marvelous Adventure in which Winnie-the-Pooh Meets Mrs. Palsgraf, 34 CAL. W. L. REv. 351, 361 (1998). 
Counterfactual thinking can also affect liability and guilt judgments in legal settings. For example, in one study, subjects read a story about a date rape and then listened to a mock lawyer's closing argument suggesting possible mutations to the story. If the argument mutated the defendant's actions so that the rape would be undone, the rapist was assigned more fault (cause, blame, and responsibility) than if his actions were mutated but the rape still would have occurred. Similarly, when the victim's actions were mutated, she was assigned more fault if the mutation would undo the rape than if the rape still would have occurred. ${ }^{188}$

The problem with counterfactuals is magnified when apologies, which may be based on feelings of guilt arising from counterfactual thinking, are admitted as evidence. These apologies effectively substitute the actor's counterfactual thinking and his conclusions about but-for causation for the conclusions of the ultimate fact-finder. They are, in some ways, his lay opinion about his ability to control the outcome by taking different actions. ${ }^{189}$ In fact, this danger is illustrated by the fact that "the features of a given situation that are focused on determine the alternatives to reality that are imagined" which in turn shapes "one's subjective affective experience with the event." 190

People are more likely to engage in counterfactual thinking - and more likely to draw causal conclusions from that counterfactual thinking - in some circumstances more than others. For example, "people are generally more likely to imagine what might have been different about the exceptional (i.e., surprising or unexpected) aspects of a given event than about the normal aspects of the same event."191 And people are more likely to engage in counterfactuals about things within their control-they imagine what they could have done differently rather than what others could have done differently. ${ }^{192}$ People also are more likely to engage in counterfactuals resulting in regret about actions more than inactions. ${ }^{193}$

188. Spellman \& Mandel, supra note 180, at 121 (citations omitted).

189. Because of the emotional, social, and moral aspects of apologies, apologies are an excellent example of lay opinion testimony. See FED. R. EvID. 701 (stating that a lay person may give nonexpert opinion testimony that is based on the person's perception and is helpful in "determining a fact in issue"). To the extent that apologies imply an opinion that the apologizer has violated some kind of norm, there is no reason to assume that the norm the apologizer perceives he has violated is remotely coterminous with legal liability, or even that the apology-receiver shares his assessment. In other words, an apology, at most, reflects an individual's subjective assessment that he has violated his own standards, whatever the origin of those standards.

190. Markman et al., supra note 172, at 593.

191. Id. at 588 (citation omitted).

192. Id. at 593-94.

193. See Spellman \& Mandel, supra note 180, at 121. 
But none of these circumstances leading to counterfactual thinking and attributions of fault (unusualness of circumstances, focus on self, and action versus inaction) have anything to do with legal blameworthiness.

For example, parents may engage in counterfactual thinking if their child dies of a preventable illness. The parents might believe that they could have prevented their child's death if they had noticed warning signs of the disease earlier. This belief could be entirely erroneous: it is possible that the early signs of the disease would have been impossible to detect. However, the parents might still reimagine events in a way that places themselves at fault. If the parents express this belief, or if alternative courses of action were presented to a finder of fact, this counterfactual attribution of fault could have legal consequences - for example, in a case of neglect.

In sum, guilt can and does occur in the absence of blameworthiness. Indeed, it can occur in the absence of any transgression at all or when the injured party is himself responsible for his injury. Engaging in counterfactual thinking can magnify guilt and lead individuals to attribute blame to themselves. ${ }^{194}$ But this attribution does not necessarily follow actual blameworthiness. Ultimately, "[f]eelings of guilt in such contexts, separate from feelings of responsibility, may be sufficient to motivate an apology." 195

\section{Social and Cultural Evidence Confirms that Apologies do not Always Reflect Fault.}

As discussed above, feelings of guilt are not always the product of actual wrongdoing or a rational belief that one has done something wrong. People may experience regret or engage in counterfactual thinking even when they have not committed a legal or moral wrong. Perhaps because of this propensity to feel guilt in the presence of injury, even in the absence of blameworthiness, apologies are often made regardless of blameworthiness.

This fact is underscored by studies on apologies and gender. Certainly women, as a gender, cannot be said to be more blameworthy than men, yet they apologize at significantly higher rates, including when the same conduct is at issue. ${ }^{196}$

\footnotetext{
194. See id.

195. Brooks et al., supra note 43, at 467.

196. See infra Section III.C.2.
} 
The propensity to apologize in the absence of blameworthiness may also relate to the fact that apologies provide social benefits even when they are entirely superfluous (made for things over which the apologizer has no control—-think "I'm sorry about the rain"). ${ }^{197}$

1. Apologies are offered and appreciated where blameworthiness is absent.

The presence and effect of superfluous apologies in our society illustrate apologies' lack of probative value. Superfluous apologies are "expressions of remorse by individuals ... who are obviously not culpable for a transgression (e.g. 'I'm sorry about your loss, the rain, bad traffic')." 198 Apologies regardless of blame, including superfluous apologies, are commonplace in our society, and for good reason. Superfluous apologies increase levels of trust for and likability of the person offering the apology. ${ }^{199}$ Through a series of four studies, Alison Brooks of Harvard Business School, and Hengchen Dai and Maurice Schweitzer, both of the Wharton School at the University of Pennsylvania, found that study participants were more likely to give money or lend a cell phone to an individual who offered a superfluous apology than to individuals who did not. ${ }^{200}$ The superfluous-apologizers were also rated as more likable and trustworthy by the study participants. ${ }^{201}$ Indeed, these effects were even more pronounced than with "traditional" apologiesapologies for things the individual could be blamed for (e.g. "I'm sorry to interrupt"). ${ }^{202}$ Similarly, research suggests that people reward those who take the blame in ambiguous situations. ${ }^{203}$

The results of a study conducted by Melinda Blackman of California State University and Elizabeth Stubbs of Case Western Reserve University illustrated that the rate at which individuals apologize - at least for minor social infractions - is likely "not significantly related to" who (the individual apologizing or the party receiving the apology) is responsible

\footnotetext{
197. See Brooks et al., supra note 43 , at 473 .

198. Id. at $472-73$.

199. See id. at 469.

200. Id. at $472-73$.

201. Id. at 469.

202. Id. at 470.

203. See id. at 473
} 
for the infraction. ${ }^{204}$ In other words, whether the apology reflected some fault of the apologizer or was entirely superfluous did not affect the rate at which apologies were offered. ${ }^{205}$

It seems likely that the psychological mechanism underlying the value of superfluous apologies is that by apologizing for the injured party's hardship the apologizer "communicates that he has taken the victim's perspective" such that he demonstrates "recognition of and concern for" the individual's suffering. ${ }^{206}$ But the psychological underpinnings of this phenomenon are less significant to the issue at hand than the dual facts that superfluous apologies are so commonplace that researchers at Harvard Business School and Wharton thought it valuable to study superfluous apologies and the study concluded that the receivers of such apologies had a positive response, suggesting an embedded social incentive to apologize in the absence of fault.

2. Gender and cultural norms related to apologies confirm their lack of probative value.

It cannot be that women, as a gender, are more blameworthy than men, yet there is evidence that women apologize at much higher rates than men. ${ }^{207}$ Indeed, one study found that women proffered 80 percent more explicit apologies than men for the exact same conduct. ${ }^{208}$ Women are also more apt to believe that behavior warrants an apology than men. ${ }^{209}$ Indeed, in one study, female participants tended to consider their behavior as more offensive than male participants and were therefore more likely to believe that they committed a transgression (perhaps explaining, in part, the increased frequency with which women apologize). ${ }^{210}$ There is some support for the notion that women feel more guilt than men. ${ }^{211}$ Whether

\footnotetext{
204. Melinda C. Blackman \& Elizabeth C. Stubbs, Apologies: Genuine Admissions of Blameworthiness or Scripted, Sympathetic Responses?, 88 PSYCH. REP. 45, $48-49$ (2001).

205. Id.

206. Brooks et al., supra note 43, at 467-68 (citation and quotation marks omitted).

207. See Karina Schumann \& Michael Ross, Why Women Apologize More than Men: Gender Differences in Thresholds for Perceiving Offensive Behavior, 21 PsYCHOL. SCI. 1649, 1653 (2010); Gonzales et al., supra note 52, at 618.

208. Gonzales et al., supra note 52, at 617.

209. See Schumann \& Ross, supra note 207, at 1653.

210. See id. at 1653-54.

211. Baumeister et al., supra note 30, at 263 ("Thus, for example, if women are indeed more prone to guilt than men, then many marriages might readily drift toward arrangements in which wives perform more than their equitable share of joint duties and resent their husbands for this.") (citations omitted).
} 
these additional apologies are motivated by guilt or not, there is no reason to think that they are in fact motivated by additional blameworthiness. In fact, to the extent that these apologies are motivated by a heightened standard for non-offensive behavior, it makes little sense as a policy matter for society to judge more harshly those who hold themselves to a higher standard and are more willing to state that their conduct has fallen short of those standards. By admitting apologies into evidence and therefore exposing apologizers to the potential for greater liability, the legal system conceivably does just that.

Similarly, there is no reason to think that Japanese people are more likely to be legally liable than Americans. Yet, they apologize more frequently, including when the other party is at fault. ${ }^{212}$ Finally - and most concerning from the perspective of its potential impact on legal outcomes - those with lower social status apologize more frequently than those with higher social status. ${ }^{213}$ Perhaps even more troubling: at least one study found that those with lower social status had a greater propensity to accept responsibility and make "I did it" statements in the face of minor infractions than higher-status individuals. ${ }^{214}$ Indeed, the historically lower status of women may be one explanation for women's propensity to apologize more frequently.

\section{The Federal Rules of Evidence Already Recognize that Similar Conduct/Statements Are Not Probative of Liability.}

The commentary to several of the Federal Rules of Evidence confirms that statements and conduct reflecting remorse, regret, or guilt after an incident are not necessarily probative of liability. For example, the commentary to Federal Rule of Evidence 407 excluding subsequent remedial measures ${ }^{215}$ explains that one reason such measures are excluded is because "[ $t$ ]he conduct is not in fact an admission, since the conduct is

212. See generally Maddux et al., supra note 142 (studying the differences between the United States and Japan in the "function and meaning" of apologies).

213. Gonzales et al., supra note 52, at 613,619 . The fact that lower status individuals may apologize more frequently and make more "I did it" statements in a country in which apologies are not excluded from evidence (based on the incorrect assumption that they are probative of liability) could result in greater liability findings and convictions for those of lower status. This subject should be further investigated to determine whether the potential for fairness concerns created by this apparent discrepancy plays out in actual legal outcomes.

214. Id. at 617.

215. FED. R. EvID. 407 ("When measures are taken that would have made an earlier injury or harm less likely to occur ...."). 
equally consistent with injury by mere accident or through contributory negligence." 216 The same commentary and analysis supports the exclusion of offers to pay medical expenses. ${ }^{217}$ Similarly, the Advisory Committee reasoned with respect to Federal Rule of Evidence 408, excluding "conduct or a statement made during compromise negotiations about the claim," 218 that "[t]he evidence is irrelevant, since the offer may be motivated by a desire for peace rather than from any concession of weakness of position." 219

The same policy reasons underlying these exceptions apply to apologies. As discussed above, apologies, like subsequent remedial measures and offers to pay medical expenses, benefit individuals and society and should consequently be encouraged. In addition, like statements made in settlement negotiations, without protections, apologies are unlikely to be offered at all. ${ }^{220}$

That in some, even many, cases there might be both a moral urge to apologize and a separate legal liability should not be a justification to discourage apologies. In this way apologies are also similar to subsequent remedial measures or offers to pay medical bills: these actions presumably arise from the injurer's subjective determination that he was in the wrong, or at least his personal discomfort with the fact that he played any part in another's injury. ${ }^{221}$ Each is arguably evidence, then, that at least he views himself as being at fault. ${ }^{22}$ But, neither subsequent remedial measures nor offers to pay medical expenses are admissible to prove liability under the Federal Rules of Evidence because of a recognition that such evidence is not particularly probative of legal fault and because of policy considerations that such actions should be encouraged. ${ }^{223}$ The same is true

216. FED. R. EVID. 407 advisory committee's notes to 1972 proposed rules.

217. See FED. R. EVID. 409 advisory committee's notes to 1972 proposed rules ("[G]enerally, evidence of payment of medical, hospital, or similar expenses of an injured party by the opposing party, is not admissible, the reason often given being that such payment or offer is usually made from humane impulses and not from an admission of liability, and that to hold otherwise would tend to discourage assistance to the injured person.").

218. FED. R. EVID. 408(a)(2).

219. FED. R. EVID. 408 advisory committee's notes to 1972 proposed rules.

220. In this way, protecting apologies can also be likened to protecting conversations with attorneys with the attorney-client privilege. As a policy matter, we recognize the importance of those conversations and also recognize that individuals are unwilling to speak freely with their attorneys if those conversations are discoverable.

221. See FED. R. EvID. 407 advisory committee's notes to 1972 proposed rules; FED. R. EVID. 409 advisory committee's notes to 1972 proposed rules.

222. See id.

223. See id. 
of apologies.

\section{Proposal: A Federal Rule Should Be Adopted to Protect FULL APOLOGIES.}

The analysis above explains why apologies are not usually evidence of liability as defined by the Federal Rules of Evidence: they are not generally probative of liability, and because people tend to wrongly assume that an apology reflects blameworthiness, they carry with them a significant risk of unfair prejudice. Theoretically, apologies should not need protection, because evidence that has no probative value (or evidence that has slight probative value that is outweighed by the risk of unfair prejudice) is not admissible. Yet, as discussed above, this particular kind of evidence is apt to be admitted regardless of its probative value. As such, leaving the admissibility of apologies to a case-by-case determination is inadequate; broader protection is needed. Further, because apologies have societal value from a policy perspective (they are capable of redressing moral and social wrongs as well as violations of personal norms), any protection for apologies should be mindful of this societal benefit. To address each of these issues, an exception to the Federal Rules of Evidence that covers full apologies should be adopted.

\section{A. Protection Should Cover "Full” Apologies.}

Partial apology protections have been the norm, presumably because they, in some ways, split the baby. They protect pure expressions of remorse, but ensure that any factual material, admissions, or acceptance of responsibility can still be used in court. But, partial apologies do not provide the same benefits as full apologies. Full apologies are more effective at redressing the harms to dignity caused by injury, filling a gap in the legal system's efforts regarding victims, and full apologies are more likely to lead to litigation efficiencies, like increasing settlements and decreasing the number of claims filed in the first place.

First, as noted above, acceptance of responsibility is a key component of redressing the dignity injury. If the goal is actually to encourage the kind of sincere and effective apologies that undo harm to dignity, full protection is necessary. Only full protection can lead to the culture change that encourages sincere and spontaneous statements of apology, because partial protection requires careful crafting of statement to avoid admissibility. As Helmreich explained, "the context of choosing one's 
words to avoid lawsuits is in itself incompatible with the concessionary, open, self-deprecating mindset characteristic of the apologetic stance."224 Further, factual material embedded in expressions of remorse are subject to the same subjective interpretation (and thus lack of legal anchoring) as the statements of remorse themselves. These statements are prone to be the result of counterfactual thinking, which tends to magnify guilt and attribution of blame to oneself.

Finally, full apologies are more likely than partial apologies to result in the settlement-generating benefits extoled by many scholars. ${ }^{225}$ The settlement-encouraging effects of full as compared to partial apologies was most aptly demonstrated by the Robbennolt study, where partial apologies left victims uncertain about whether to settle, but full apologies resulted in substantially more victims accepting settlement offers. ${ }^{226}$ Presumably, this is because fault-admitting apologies tend to be viewed as more sincere. ${ }^{227}$ Indeed, as Robbennolt concluded, "providing evidentiary protection for apologies may serve to encourage the offering of apologies ... without diminishing the value and effectiveness of apologies so offered. ${ }^{2228}$

\section{B. Protection Should Take the Form of an Exclusion in the Federal Rules of Evidence.}

State limitations are inadequate to address the admissibility (or, more accurately, inadmissibility) of apologies. First, state limitations, by their nature, only apply to litigation within an individual state. Cases removed to federal court or brought in a different state are not covered. In a world where many people cross state lines daily, a state-by-state approach gives little comfort to a would-be-apologizer that his statements will not center prominently in litigation. Furthermore, even though the Federal Rules of Evidence do not apply in state courts, they serve as a model for the evidentiary rules of many states ${ }^{229}$ and govern all cases in federal courts,

224. Helmreich, supra note 3, at 573.

225. See, e.g., Robbennolt, supra note 98, at 505 (noting that it is "full, responsibility-accepting, apologies that have a positive impact on settlement decisionmaking [sic]").

226. Id. at $485-86$.

227. Helmreich, supra note 3 , at 602 .

228. Robbennolt, supra note 98, at 504.

229. See, e.g., Lauren Gailey, "I'm Sorry" as Evidence? Why the Federal Rules of Evidence Should Include a New Specialized Relevance Rule to Protect Physicians, 82 DEF. CounS. J. 172, 173 (2015) (advocating for a federal rule excluding apologies from physicians and noting that "[b]ecause 
including those removed from state courts. ${ }^{230}$ As such, even though an exception for apologies within the Federal Rules of Evidence would not necessarily cover every apology, everywhere, it would likely come close. Further, it would likely be much more effective at encouraging apologies than the piecemeal approach taken thus far.

Second, and equally important, most state limitations fall short of recognizing that apologies, by their very nature, are not reliably probative of liability. As such, state limitations, by and large, protect only "partial" rather than "full" apologies. ${ }^{231}$

The resulting landscape is that some kinds of apologies are protected in some places. But, the probative value of an apology is not dependent on whether it is uttered in Nebraska or Kansas, and the policy-related reasons to encourage apologies are not well served by admissibility outcomes that vary by state. Without a federal rule, protection is spotty and inconsistent in state courts, and there is no protection in federal courts; such that an apologetic person could not be certain that his apology would be protected, even in a region where many states offer full protection, because he could be sued in federal court in that state instead. Consistency and predictability are always a goal of law, but they are especially important when trying to encourage behavior, and especially when the most ubiquitous example of instances where apologies are needed involves moving vehicles. If spontaneous and sincere apologies are the best, one who causes harm should not be expected to pause his spontaneous and sincere apology to check his map and his local rules of evidence and evaluate whether his apology will be admissible in some later lawsuit. If spontaneous and sincere apologies are to be encouraged, they should be protected consistently and fully. Finally, because the Federal Rules of Evidence so often serve as a template for state rules, the adoption of a federal rule is likely to effectively result in adoption of a similar rule everywhere.

The Federal Rules of Evidence already recognize several circumstances in which statements or conduct could be undertaken because of legal liability or for some other reason. For example, subsequent remedial measures could be undertaken because prior

\footnotetext{
many states' evidence rules are modeled after the Federal Rules, such an addition would be a persuasive and effective means of demonstrating the federal government's commitment to fostering the doctor-patient relationship - and of encouraging the states to do the same").

230. See FED. R. EvID. 101(a) ("These rules apply to proceedings in United States courts.").

231. See Runnels, supra note 124, at $151 \mathrm{n} .70$ (citing to thirty-five state statutes that protect such partial apologies).
} 
measures were legally inadequate or simply to avoid future accidents. ${ }^{232}$ Similarly, offers to pay medical expenses could reflect an acceptance of legal liability for injury or a benevolent desire to help an injured party. ${ }^{233}$ Offers to settle and statements made in settlement negotiations could similarly be made for reasons that do not necessarily reflect the strength or weakness of a party's legal position-for example to keep the peace or avoid litigation costs. ${ }^{234}$ In each instance, the Advisory Committee explained that this conduct is not actually an admission of fault because it is equally consistent with other legal blamelessness. ${ }^{235}$ In all of these instances, a social policy of encouraging, or at least not discouraging, the excluded conduct or statements weighed heavily in favor of excluding these (at most marginally probative) acts and statements. ${ }^{236}$ The same is true in the context of apologies.

\section{Addressing Potential Criticisms.}

Three primary critiques are typically levied at pieces arguing for protection of apologies in the evidentiary system: (1) that important evidence is lost by the protection of apologies, (2) that the resolutionencouraging properties of apologies will be leveraged by wrongdoers to promote insincere apologies, and (3) that victims, particularly those presented with such insincere apologies, will settle for less than they should because they will be moved by apologies. None of these critiques justifies foregoing the rule proposed above.

1. No evidence is truly lost.

An obvious critique to excluding apologies, particularly full

232. See FED. R. EvID. 407 advisory committee's notes to 1972 proposed rules.

233. See FED. R. EvID. 409 advisory committee's notes to 1972 proposed rules.

234. FED. R. EVID. 408 advisory committee's notes to 1972 proposed rules.

235. FED. R. EVID. 407 advisory committee's notes to 1972 proposed rules; FED. R. EVID. 409 advisory committee's notes to 1972 proposed rules. This reasoning holds regardless of the particular hearsay exception-e.g. statement against interest or excited utterance - under which the apology would otherwise be admitted.

236. See FED. R. EvID. 407 advisory committee's notes to 1972 proposed rules ("The other, and more impressive, ground for exclusion rests on a social policy of encouraging people to take, or at least not discouraging them from taking, steps in furtherance of added safety."); FED. R. EvID. 408 advisory committee's notes to 1972 proposed rules ("A more consistently impressive ground is promotion of the public policy favoring the compromise and settlement of disputes."); FED. R. EVID. 409 advisory committee's notes to 1972 proposed rules (explaining that failing to exclude offers to pay medical expenses "would tend to discourage assistance to the injured person"). 
apologies, in the Federal Rules of Evidence is that some apologies may contain factual material that could, in fact, be probative of an issue in the case. $^{237}$ It goes hand-in-hand with a related critique: that offering protection to full apologies is essentially refusing admission of "full confession[s], simply because the speaker uttered the magic words, 'I'm sorry' before admitting liability," which some argue is a "dangerous policy and may significantly weaken an individual's ability to prove their case." 238 In short, the argument is that important evidence could be lost by excluding factual information contained in apologies. To be clear, this Article argues that apologies are not probative of legal liability. Indeed, the "factual information" provided as a result of counterfactuals is just as suspect as the apologies it engenders. But, even if apologies were probative, their exclusion would not result in a loss of evidence sufficient to justify discouraging apologies.

a. Any loss of apology "evidence" is on a micro-level only.

First, this critique assumes that confessions of liability would happen regardless of the apology and that a rule protecting the confession with the apology encourages wrongdoers to throw in an "I'm sorry" at the end to render otherwise admissible evidence inadmissible. ${ }^{239}$ But, this misconstrues the landscape of apologies. The whole point of rules to encourage apologies is that the social and psychological drive to apologize is being squelched by a fear of liability. Presumably, any loss of evidence would happen only on the micro-level. If one assumes that more apologies would be offered precisely because the would-be-apologizer would not be threatened with liability implications from his apology, then without the apology rule there would be no "confession" of liability. In other words, the impact is only on an individual case, after the fact, when the apology and "confession" are excluded, not to society as a whole, because without the apology protection there would be no apology or confession of liability in the first place. One point of such a rule is to encourage apologies where there would otherwise most likely be none. Assuming that happens, then, no evidence is lost on a macro-level because any evidence that is excluded never would have been provided if not for the exception. In other words, if protection for full apologies encourages more full apologies and those

237. See Farmer, supra note 3, at 262.

238. Id.

239. Id. 
apologies include admissions of fact (however suspect they may be), society has lost nothing from the current state of affairs: evidence is excluded that would not have existed but for the rule.

b. The Federal Rules of Evidence contemplate the loss of evidence in similar circumstances.

Second, the Federal Rules already contemplate the loss of evidence when that evidence is not actually probative of the legal issues and excluding it furthers public policy. ${ }^{240}$ Excluding apologies because these same justifications apply, despite the possibility that some potential evidence could be lost in some cases, is a no-brainer.

Perhaps most analogous to the apology context are statements provided in the course of settlement negotiations. Federal Rule of Evidence 408 provides that "conduct or a statement made during compromise negotiations about the claim" is inadmissible for almost any purpose, including impeachment. ${ }^{241}$ Such excluded statements could, of course, include apologies, ${ }^{242}$ but they might also include other statements of a party's interpretation of the "facts," including, like apologies, an admission of fault and factual details related to liability. These statements, when made in the context of settlement negotiations, are inadmissible. Period. This is so even if the content was probative of the issues in the case and regardless of how valuable it would be to the offering party at trial-even if it included the "full confession" referenced above. ${ }^{243}$

The Advisory Committee recognized two reasons such statements should be excluded, and both apply equally to apologies. First, as the Advisory Committee explained, "[t]he evidence is irrelevant, since the offer may be motivated by a desire for peace rather than from any concession of weakness of position." ${ }^{244}$ In other words, statements made in settlement negotiations, like statements made as part of an apology, are irrelevant because their content is not necessarily probative of legal liability. Second, such statements are excluded because of the promotion

240. See, e.g., FED. R. EvID. 408 advisory committee's notes to 1972 proposed rules.

241. FED. R. EVID. 408(a)(2).

242. Runnels, supra note 124, at 140 (noting that "an apology made during settlement negotiations generally should not be admissible to prove liability"). As Runnels explained, however, "the apology must be made during and not before settlement negotiations," undermining many of the policy goals of encouraging apologies in the first place. Id.

243. Rule 408 prohibits statements in settlement negotiations from being offered "on behalf of any party ...." FED. R. EvID. 408(a).

244. FED. R. EVID. 408 advisory committee's notes to 1972 proposed rules. 
of public policy. ${ }^{245}$ With apologies, too, public policy is promoted when they are excluded.

c. An evidentiary exclusion would not prevent discovery based on the content of the apology.

Finally, and relatedly, excluding apologies from admission in court does not limit the ability of apology-receivers and their lawyers to use the content of those apologies in discovery. In this way, too, any potential "loss" of evidence as a result of excluding apologies as evidence is mitigated. The discovery rules are by nature broader than admissible evidence. ${ }^{246}$ Under Federal Rule of Civil Procedure 26, parties may obtain discovery of relevant, nonprivileged information so long as the information sought is "proportional to the needs of the case ...."247 Nothing in the proposed evidence rule would limit the application of Federal Rule of Civil Procedure 26. Similarly, no part of the proposed rule asks apology-receivers to unhear the content of the apology. Apology-receivers and their lawyers may use the content of the apology to guide their investigation in discovery. To the extent the opinions expressed in an apology are supported by the underlying facts, an apologyreceiver may use those underlying facts to prove his case.

Further, the supposed loss of evidence becomes even narrower when viewed with this discovery aspect in mind. I noted above that the exclusion of apologies is presumably only of concern in the narrow span on the spectrum of liability in which liability is questionable and the presence of an apology would lead the fact-finder to conclude that the apologizer was liable when otherwise it would conclude that he was not. That is, the concern is only operative when the presence of an apology would tip the scales in favor of liability. Given that the rule would not eliminate the discovery of facts related to such apologies, the area of concern becomes even narrower. Excluding an apology would only

245. Id. In the settlement context the public policy promoted is that of "favoring the compromise and settlement of disputes." Id. Interestingly, many commentators cite precisely this justification for excluding apologies as evidence. Though this article argues for exclusion of apologies for other reasons, the fact that this justification was sufficient for the Advisory Committee to recommend excluding statements made in the course of settlement negotiations and that the same policy would also be furthered by excluding apologies provides further indication that exclusion in the Federal Rules of Evidence is an appropriate solution.

246. See FED. R. CIV. P. 26(b)(1) ("Information within this scope of discovery need not be admissible in evidence to be discoverable.").

247. Id. 
eliminate key evidence where the presence of the apology would tip the scales and where the facts underlying the apology could not be substantiated or supported in any other way. This scenario calls into question whether this narrow circumstance is actually the precise circumstance under which the apology protection is most important: if the apology tips the scales and there is no other evidence of the supposed liability-proving facts than the apology, perhaps those facts are the result of erroneous counterfactual thinking that does not reflect actual blameworthiness and should not give rise to liability in any case.

In sum, although it is true that there are hypothetical apology-receivers who would be deprived of the ability to present apologies as evidence of liability, this situation is not unlike other situations contemplated by Federal Rules of Evidence, and the apology-receiver could still use the apology in discovery to gain access to relevant facts. Indeed, because apologies are not ultimately probative of liability, their loss is not concerning.

2. The risk of insincere apologies is overblown.

A second critique suggests that protections might result in an increase in the number of insincere apologies, and studies show that apologies viewed as insincere could hinder the litigation process. A common formulation of this argument is that "[e]videntiary exclusions rob apologies of their moral content and, in so doing, undermine the sincerity and, ultimately, the healing efficacy of apologies." 248

First, because the overriding policy considerations for excluding apologies go beyond litigation efficiencies, there are reasons to encourage apologies even if some insincere apologies hinder the litigation process. The most common critique of this genre suggests that protection for apologies might result in strategic calculations in commercial settings, whereby commercial actors would choose to commit torts and then apologize because it would cost less than avoiding the harm in the first place. This is similar to an efficient breach argument in the contract setting. But, is there really any reason to think that actors undertake that kind of analysis when evaluating possible negligence? Surely society does not expect that geriatric surgeons are less careful, or that drivers in the parking lot of a senior living facility are more likely to choose carelessness because the anticipated economic loss is less for the average older patient,

248. Jesson \& Knapp, supra note 97, at 1438 (citations omitted). 
or that hospitals that largely treat Medicaid patients engage in fewer patient safety efforts because they calculate that economic losses for negligence are likely to be lower among this (on average) lower income population. To the extent deterrence is a goal of the tort system, its intention is presumably to deter all forms of negligence because of the prospect of liability, not only those forms of negligence that are most costly.

Finally, and importantly, Robbennolt found "no evidence to suggest that protected apologies will be less effective or less valued by claimants than unprotected apologies." 249

3. The risk of inappropriate settlement assumes that the current tort system provides recovery for dignity injuries.

A final critique of a rule protecting full apologies is that such a rule might result in injured parties accepting less than they should in settlement negotiations. ${ }^{250}$ But, legal value is the value the parties agree to or the jury awards, and to the extent the monetary value is being inflated due to the affront to dignity experienced by the harmed party, then apologies are a good thing because they address this separate harm. One might argue that where a dignity injury is encouraging an injured party to seek the full amount of his damages, an apology that decreases that final number is a bad thing. But, arguments that apologies reduce settlements to levels below that which adequately compensate victims effectively presumes that victims do not know what is best for them, place no value on the separate incompensable-under-the-legal-system dignity harm, and simultaneously place so much value on the redress of that harm that they devalue their other legal claims as soon as it has been remedied. Even if this were true, this is why injured parties have lawyers. Indeed, studies have confirmed that lawyers are inherently more skeptical of apologies than lay persons and would do well to advise their clients of the economic value of their claims. In the usual negligence case, moreover, lawyers operate on a contingency fee arrangement, so encouraging their clients to accept settlement offers that fail to adequately compensate those clients for their injuries harms both the lawyer and his client.

Note that one of the virtues extolled of apology programs in the medical malpractice context is that many claims are never brought or are

249. Robbennolt, supra note 98, at 504.

250. See Arbel \& Kaplan, supra note 113, at 1200-03. 
settled for small amounts without attorney involvement. While in these circumstances a client is presumably not relying on counsel to ensure that she is not receiving less than she should for her injuries, that client is also not paying counsel, or court fees, which can easily reduce any award by nearly 50 percent. ${ }^{251}$

\section{CONCLUSION}

Mistaken assumptions about the probative value of apologies lead to the erroneous inference that they are (and should be) admissible as evidence of legal fault. Yet, psychological studies confirm that people apologize frequently in the absence of fault. A moral analysis of apologies confirms that they are appropriate in circumstances where an individual is involved in a situation with a negative outcome. Further, cultural evidence reflecting a disparate use of apologies along gender, status, and ethnic lines further reflects their lack of probative value. When this lack of probative value is combined with the individual and societal benefits from apologies, encouraging their use makes good sense. An exception in the Federal Rules of Evidence would ensure consistent treatment for apologies across jurisdictions, both because it would ensure consistent treatment in the federal system and because many states use the Federal Rules of Evidence as a model for their own evidentiary rules. Such an exception is not novel; the Federal Rules of Evidence grant exceptions for other acts or statements that benefit society and individuals but have minimal probative value, e.g. subsequent remedial measures. Apologies, too, should be excluded as an exception in the Federal Rules of Evidence.

251. See id. at 1206 n.23 (citing Mitchell Polinsky \& Steven Shavell, The Uneasy Case for Product Liability, 123 HARV. L. REV. 1437, 1470 (2010)). Just because settlements may be reduced by an apology, or even because some individuals might accept less than their counterparty's valuation of damages, this does not necessarily mean that the reduction in settlement amount is inappropriate. These generalized statistics cannot account for the nuances of cases, because people settle for all sorts of reasons - they may just want to get on with life, or maybe they have an overly pessimistic lawyer who advises them that they were likely to lose at trial - there are many possible explanations for seemingly unfair settlement anecdotes. 